Chapman University

Chapman University Digital Commons

Business Faculty Articles and Research

Business

$3-2010$

\title{
An Empirical Examination Of the "Rule Of Three": Strategy Implications For Top Management, Marketers, and Investors
}

\author{
Can Uslay \\ Chapman University \\ Ayca Altintig \\ Chapman University \\ Robert D. Windsor \\ Emory University
}

Follow this and additional works at: https://digitalcommons.chapman.edu/business_articles

Part of the Business Administration, Management, and Operations Commons

\section{Recommended Citation}

Uslay, Can, Z. Ayca Altintig, and Robert D. Winsor. "An empirical examination of the "rule of three": strategy implications for top management, marketers, and investors." Journal of Marketing 74.2 (2010): 20-39. DOI:10.1509/jmkg.74.2.20

This Article is brought to you for free and open access by the Business at Chapman University Digital Commons. It has been accepted for inclusion in Business Faculty Articles and Research by an authorized administrator of Chapman University Digital Commons. For more information, please contact laughtin@chapman.edu. 


\section{An Empirical Examination Of the "Rule Of Three": Strategy Implications For Top Management, Marketers, and Investors}

\section{Comments}

This article was originally published in Journal of Marketing, volume 74, issue 2, in 2010. DOI: 10.1509/ jmkg.74.2.20

\section{Copyright}

American Marketing Association 


\section{An Empirical Examination of the "Rule of Three": Strategy Implications for Top Management, Marketers, and Investors}

This study represents the first empirical examination of the "Rule of Three," a theory at odds with several popular notions regarding industry structure and business performance, including the positive linear market shareperformance relationship. In general, the findings from more than 160 industries support the Rule of Three and provide five main insights: First, there appears to be a prevalent competitive structure for mature industries in which three "generalist" firms control the market. Second, industries that conform to this structure tend to perform better than industries with a fewer or greater number of generalists. Third, both "specialists" and generalists outperform firms that are "stuck in the middle." Fourth, the performance benefits of market leadership appear to diminish with excessive market share. Fifth, the Rule of Three industry structure and its influence over firm profitability do not appear to be priced appropriately by financial markets. The authors discuss the implications for multiple stakeholders.

Keywords: Rule of Three, market share, marketing strategy, industry structure, profitability, market concentration, number of firms, generalists, specialists

S heth and Sisodia (2002) published The Rule of Three: Surviving and Thriving in Competitive Markets to critical acclaim. Their book on market evolution and dynamics has wide-ranging corporate, marketing, investment, and policy implications, some of which are at odds with the positive linear market share-performance relationship that has been heavily debated in marketing and strategy literature (e.g., Buzzell 2004; Buzzell and Gale 1987; Ramanujam and Venkatraman 1984; Rumelt and Wensley 1981; Szymanski, Bharadwaj, and Varadarajan 1993). Sheth and Sisodia make the case that an industry structure consisting of three large generalists and numerous smaller specialists generates a competitive environment that is "optimal" for firm stability and profitability. In addition, they argue that a nonlinear relationship between market

Can Uslay is Assistant Professor of Marketing (e-mail: uslay @ chapman.edu), and Z. Ayca Altintig is Assistant Professor of Finance (e-mail: altintig@chapman.edu), Argyros School of Business and Economics, Chapman University. Robert D. Winsor is Professor of Marketing, College of Business Administration, Loyola Marymount University (e-mail: rwinsor@Imu.edu). The authors thank Philip Kotler, Glenn Carroll, David Stewart, Naresh Malhotra, Goutam Challagalla, Peren Arin, Ekaterina Karniouchina, Niklas Myhr, Glenn Omura, Koen Pauwels, Kapil Tuli, and the three anonymous JM reviewers for their helpful comments on previous versions of this article, as well as Jagdish Sheth and Rajendra Sisodia for their encouragement and support. They acknowledge helpful comments of participants at the 2007 INFORMS Marketing Science Conference in Singapore, the Fall 2008 California Corporate Finance Conference in Los Angeles, and the Fall 2008 Chapman University seminar series. They also thank Birva Saraiya and Evrim Erdoğan for research assistance. share and profitability exists in these structures, such that both small- and large-share firms (within boundary conditions) can achieve high profitability, while midsized firms are destined to languish. In summary, Sheth and Sisodia theorize that (1) industries tend to evolve toward a dynamic equilibrium with a specific structure and distribution of firm sizes and (2) a company's market share and degree of strategic focus are jointly related to its performance.

The Rule of Three theory has been publicized in a variety of practitioner-oriented publications. ${ }^{1}$ However, to our knowledge, this current study represents the first attempt to formally state related hypotheses and empirically test the validity of the theory. In addition, we examine the degree to which financial markets incorporate its implications in firm valuation.

In developing the hypotheses, we augment the work of Sheth and Sisodia (2002) with literature on ecological resource partitioning (Carroll 1985, 1997) and industrial

${ }^{1}$ The Rule of Three (Sheth and Sisodia 2002) reviews or references have appeared in the Wall Street Journal (Sheth and Sisodia 1998), Harvard Business Review (Landry 2002), Academy of Management Executive (Saffersfone 2002), Entrepreneur (Henricks 2002), and Marketing Management (Gordon 2001), among others. It was a finalist for the Berry-American Marketing Association Book Prize. Philip Kotler (Sheth and Sisodia 2002, cover) praises it as "one of the most provocative and original business books to come out in years." The Rule of Three arguably qualifies as a theory because it includes systematically related statements and lawlike generalizations that are empirically testable (Hunt 2002, p. 193). 
organization (Porter 1980; Scherer 1980). We then test these hypotheses using data from more than 160 industries and two base-time periods (1997 and 2002). Our findings suggest that firm performance is indeed influenced by both industry structure and market share in a manner predicted by the Rule of Three, and they yield several important corporate, marketing, and investment implications.

\section{The Market Share-Performance Relationship: Challenging Conventional Wisdom}

In the vast preponderance of industries, distributions of firm sizes within an industry are highly skewed, such that a few large firms dominate while many smaller firms occupy minor market share positions (Axtell 2001; Buzzell 1981; Gans and Quiggin 2003; Ijiri and Simon 1977; Quandt 1966). In their seminal work, Simon and Bonini (1958) characterize numerous prior studies of firm size distribution as "monotonously similar," and Axtell (2006, p. 3) more recently remarked that "data of such vast regularity are highly unusual in the social sciences."

Viewing the issue of firm size distribution as strategic and cost driven, Bruce Henderson, at the helm of the Boston Consulting Group (BCG), observed that stable and competitive markets are regularly dominated by three primary competitors, and he described this pattern as The Rule of Three and Four (BCG 1976; Henderson 1979). Henderson also claimed that the market shares of these three firms are approximately distributed in the ratio of 4:2:1 (BCG 1976).

Of particular importance to all business disciplines is the widely held conviction that market share and profitability are strongly positively related, both for U.S. markets (Buzzell and Gale 1987) and for foreign markets (Douglas and Craig 1983; Kotabe et al. 1991). According to the majority of studies on this topic, there is a linear (or at least monotonic) positive relationship between market share and financial performance (Branch 1980; Buzzell 2004; Kohli, Venkatraman, and Grant 1990; Shepherd 1972; Szymanski, Bharadwaj, and Varadarajan 1993). Bharadwaj and Varadarajan (2005) review seven schools of thought and directly link market share to financial performance in their integrated model. Buzzell and Gale (1987, p. 8) argue that every 10 points of market share gain leads to approximately 3.5 points of return-on-investment (ROI) increase.

Conversely, a significant number of studies have challenged the conventional wisdom, arguing that (1) the relationship between market share and profitability is modest and merely a spurious covariation that is solely or largely due to unidentifiable factors (Boulding and Staelin 1990; Jacobson 1990; Rumelt and Wensley 1981); (2) the relationship is context specific (Prescott, Kohli, and Venkatraman 1986); (3) the existence of the relationship does not necessarily imply that market share causes profitability (Demsetz 1973); (4) most industries do not display this relationship, but the overall empirical evidence is likely skewed by a minority of industries that display unusually strong positive correlations between market share and profitability
(Schmalensee 1989; Slade 2004; Wensley 1997); and (5) small firms can also commonly achieve high profitability, suggesting that the relationship to market share is not a simple linear function (Hamermesh, Anderson, and Harris 1978; Porter 1980; Schwalbach 1991; Woo and Cooper 1981, 1982). Finally, several researchers have challenged the Profit Impact of Market Strategy (PIMS) data set on which this relationship has typically been advanced (e.g., Anderson and Paine 1978; Ramanujam and Venkatraman 1984). Learning to date overwhelmingly depends on the PIMS foundation (Farris and Moore 2004), though a metaanalysis concluded that its use has led to inflated estimates of the market share-profitability relationship (Szymanski, Bharadwaj, and Varadarajan 1993).

In Table 1, we present the reasons the pursuit of market share might be simultaneously desirable or undesirable for different stakeholders. It appears that there is no conclusive verdict on the exact nature of this key relationship. Concurrent with our empirical examination, we respond to Kohli, Venkatraman, and Grant's (1990) call to examine the market share-profitability relationship using stock marketbased performance measures, alternative operationalizations of market share and performance, nonlinear models, and non-PIMS data.

\section{The Rule of Three Theory and Hypotheses}

Sheth and Sisodia (2002) draw from the extant literature and an extensive range of observations to develop the Rule of Three theory. They argue that industries evolve in a predictable way toward a dynamic equilibrium. This evolution is suggested to be governed by a competitive process (reminiscent of the Schumpeterian evolution theorized by Nelson and Winter [1982]) in which new and existing firms are winnowed and consolidated. Sheth and Sisodia posit that absent regulatory restraints or anticompetitive practices, any given industry is expected to evolve and converge toward an optimal structure in which there are three full-line generalists that are volume driven, numerous successful small specialists that are margin driven, and high overall industry performance as measured by return on assets (ROA). However, this convergence can take several decades even without regulatory restraints. Following Sheth and Sisodia, we define a generalist as a firm that serves the general market with a full line of offerings and has $10 \%-40 \%$ or higher market share. In the vast majority of industries with three generalists, their combined share is well above $50 \%$ and can approach $70 \%-90 \%$. A specialist is defined as a firm that focuses on a differentiated product or market niche and possesses less than 5\% market share (Sheth and Sisodia 2002). The convergence to three generalists is driven by four influences that serve both to increase firm efficiency and to govern the nature of competition within the industry: industry cost structures and shared infrastructures, government intervention or deregulation, industry consolidation or globalization, and the creation of technological process or product standards (Sheth and Sisodia 2002; see also Berger, Demsetz, and Strahan 1999; Klepper and Simons 1997; Mascarenhas 1995; Scherer 1980). 


\begin{tabular}{|c|c|c|}
\hline & Advantages of High Market Share & Disadvantages of High Market Share \\
\hline Top management & $\begin{array}{l}\text {-Creates efficiency (i.e., cost advantage) through } \\
\text { economies of scale (Demsetz 1986). } \\
\text {-Cost advantage can serve as a barrier to entry } \\
\text { (Porter 1980). } \\
\text {-Demonstrates market leadership/power. } \\
\text { - Signals management skill (Ailawadi, Farris, and } \\
\text { Parry 1999). } \\
\text { - It is prominently linked to executive } \\
\text { compensation/bonus (Ritz 2008). }\end{array}$ & $\begin{array}{l}\text {-Benefits are based on management folklore, and } \\
\text { market share orientation can shrink profits } \\
\text { (Armstrong and Collopy 1996). } \\
\text {-May decrease organizational aspirations and lull the } \\
\text { firm to sleep (Boulding and Staelin 1993; Drucker } \\
\text { 1982). } \\
\text {-May limit future growth opportunities. }\end{array}$ \\
\hline Marketing & $\begin{array}{l}\text { - Consumers can perceive it as a sign of quality } \\
\text { (Smallwood and Conlisk 1979) or better value } \\
\text { proposition (Hellofs and Jacobson 1999). } \\
\text { •Decreases perceived social risk for customers } \\
\text { (Cialdini 1993). } \\
\text { - Typically correlates with customer loyalty and sales } \\
\text { stability (Ehrenberg, Goodhardt, and Barwise 1990; } \\
\text { Sharp et al. 2002). } \\
\text {-More efficient use of marketing dollars. } \\
\text {-Brand, channel, and customer equity can serve as } \\
\text { barriers to entry (Karakaya and Stahl 1989). }\end{array}$ & $\begin{array}{l}\text { - Can lead to decreased customer satisfaction } \\
\text { (Fornell 1995; e.g., AOL). } \\
\text {-Will decay the appeal of exclusivity for prestigious } \\
\text { brands. } \\
\text { - Benefits of scale and scope are limited in } \\
\text { differentiated (i.e., most branded) markets. }\end{array}$ \\
\hline Finance & $\begin{array}{l}\text {-Decreases firm-specific (default) risk. } \\
\text {-Increases analyst coverage and liquidity. }\end{array}$ & $\begin{array}{l}\text {-Increases industry-specific (downside) risk (e.g., } \\
\text { Bear Stearns, Lehman Brothers). } \\
\text {-Increases exposure to systematic risk. }\end{array}$ \\
\hline Public policy & $\begin{array}{l}\text {-Network externalities can increase consumer } \\
\text { welfare. }\end{array}$ & $\begin{array}{l}\text {-It leads to market power and collusion (Bain 1956). } \\
\text {-More pressure from consumer advocacy groups } \\
\text { (Bloom and Kotler 1975). }\end{array}$ \\
\hline
\end{tabular}

Ecological resource partitioning theory (Carroll 1985, 1997) focuses on the competitive dynamics between/among generalists and specialists and provides ample support for the evolution toward few generalists and the Rule of Three theory. Simply put, abundant and wide-ranging resources in an industry lead to a proliferation of generalists, which then attract and allow for the formation of numerous specialists that pursue peripheral niches within the market (Carroll 1985). However, in the process, the resource base per generalist is also stretched thinner. The degree of strategic overlap among generalists is high, and they compete directly with one another for the same central scarce resources, decreasing their overall survival rate. In contrast, specialists do not compete as intensely because of their differentiation and focus in niche markets (Swaminathan 2001). In summary, resource partitioning theory predicts that as markets mature and become more concentrated, the death rate (birth rate) of generalists increases (decreases), and the death rate (birth rate) of specialists decreases (increases) (Carroll 1985; Carroll, Dobrev, and Swaminathan 2002; Swaminathan 2001). Scale economies benefit larger generalists more, jeopardizing the success and survival of small- to midsized generalists, thus further increasing market concentration (Dobrev and Carroll 2003; Peli and Nooteboom 1999). Resource partitioning theory predictions have been empirically supported in a diverse range of single-industry studies, including the film industry, banking, newspapers, the early and later deregulated telephone industry, microprocessor manufacturers, breweries, and wineries (Mezias and Mezias
2000). Resource partitioning theory (Carroll 1985) and the Rule of Three theory (Sheth and Sisodia 2002) appear to be in agreement regarding the basic evolution of markets; however the Rule of Three is more outcome than process oriented and predicts convergence to three generalists.

According to Sheth and Sisodia (2002), the Rule of Three industry structure (in the context of industry structure, we use the term "R3"), defined as a mature and competitive industry with exactly three generalists, is optimal because the three generalists act as the tripod that stabilizes the industry against hypercompetition or collusion. Industries with more than three generalists are expected to experience lower profitability because of more intensive competition and the resultant pressure on profit margins. "The tendency to maximize joint industry profits breaks down if the industry contains more than three or four firms of substantial size" (Miller 1967, p. 264). Additional generalists are not necessary to maintain the competitive balance and thus become expendable during the drive for efficiency (Sheth and Sisodia 2002).

More generalists imply less multimarket contact between any two generalists, which diminishes opportunities for tacit collusion through "mutual forbearance" and serves to enhance competitive intensity (Jayachandran, Gimeno, and Varadarajan 1999). This outcome can be observed through the increased likelihood and incidence of price wars or other means of retaliation (e.g., competing sales promotions, advertising expenditure, distribution scope, new product introductions; see Kuester, Homburg, 
and Robertson 1999) among a greater number of generalists. For example, generalists (in the machine tool and computer workstation manufacturing industries) have been found to introduce new products at a higher rate than specialists and to suffer more because of too many and too risky product introductions (Sorenson et al. 2006).

Somewhat counterintuitively, the Rule of Three predicts that industries with fewer than three generalists will also experience decreased profitability (Sheth and Sisodia 2002). When only two generalists exist within a market, each is more likely to engage in predatory competition (leading to the elimination of one firm) or collusion (tacit or otherwise), either of which will ultimately result in de facto monopoly and, thus, complacency, decreased innovation, and decreased quality (Sheth and Sisodia 2002). With three generalists, the possibility of a retaliatory alliance between two competitors (i.e., balance of power) discourages/ prevents predatory attacks (Sheth and Sisodia 2002). In other words, the R3 industry structure should offer an optimal mix of competition, collaboration, and customer value in mature industries, resulting in higher profitability.

Resource partitioning theory also supports this expectation, with the reasoning that two generalist firms would not be able to cover as much resource space as three generalists, implying lower utilization of the market's potential and, thus, lower overall profitability (Boone, Carroll, and Van Witteloostuijn 2004; Swaminathan 2001). Moreover, (fewer) generalists may be preoccupied with market defense and more likely to build market entry barriers through excessive product/brand proliferation (Mainkar, Lubatkin, and Schulze 2006; Sorenson et al. 2006) and/or limit/penetration pricing (Caves, Fortunato, and Ghemawat 1984; Porter 1980). Therefore, such industries might also experience lower profitability due to excessive (rather than too little) innovation or lower margins resulting from proactive (rather than reactive) strategies.

Furthermore, the mere presence of only two generalists with high profitability might itself signal a larger market gap and entice new competitors (Scherer 1980). Such a new competitor may (1) likely fail during entry but depress industry profitability until it exits (or is acquired), (2) survive initially but fail to acquire the market share necessary to establish itself as a viable player and subsequently depress industry profitability (see the discussion for "the ditch"), or (3) succeed as a healthy generalist and thus cause convergence to three generalists in accordance with the Rule of Three. ${ }^{2}$ In either scenario, it appears that the Rule of Three expectation prevails.

Finally, further support for the Rule of Three's theory of the optimal generalist population stems from game theory literature. From a meta-analysis of extant experimental literature and a series of oligopoly experiments, Huck, Normann, and Oechssler (2004, p. 435) conclude that "[t]wo are few and four are many." They observe collusion within duopolies, whereas markets with four or five players tend to

2Naturally, a new specialist may also be lured to enter and influence industry profitability. However, the Rule of Three has no specific prediction regarding the difference in average profitability for new specialists in a two- versus three-generalist industry setting. be overly competitive, driving producers' profits toward zero. Only three-player markets consistently generated Nash equilibrium (optimal) outcomes.

We capture the Rule of Three arguments regarding industry structure and the relationship between market share and profitability with the following hypotheses:

$\mathrm{H}_{1}$ : An industry structure consisting of three generalists is more prevalent than other structures for mature industries.

$\mathrm{H}_{2}$ : R3 industries (i.e., those with three generalists) perform better than those with more than three generalists.

$\mathrm{H}_{3}$ : R3 industries (i.e., those with three generalists) perform better than those with fewer than three generalists.

Sheth and Sisodia (2002) argue that generalists (with $10 \%-40 \%$ market share) benefit from a positive relationship between market share and performance (see Figure 1). The two most common economic explanations as to why market share leads to higher profitability are efficiency (achieved through economies of scale and experience) and market power (Jacobson 1988). According to the efficiency argument, economies of scale that result from higher sales volumes can provide cost advantages to larger firms (Demsetz 1986; Gale and Branch 1982; Porter 1980; Sharp et al. 2002). Conversely, market power (which results when a firm is larger than many of its rivals) can allow firms to extract concessions from channel members, engage in collusive behavior with similarly sized rivals, or maintain supranormal prices within the marketplace (Bain 1956; Boulding and Staelin 1993; Slade 2004; Stigler 1964). Market share can also affect the perceived quality of firms' offerings through signaling, by creating network externalities, and as a distinct attribute in customers' quality assessments (for other advantages, see Table 1). Thus, largemarket-share generalists would be expected to outperform their smaller generalist rivals.

Small (specialist) firms that are likely to be operating at suboptimal scales of efficiency (Audretsch 1995; Audretsch, Prince, and Thurik 1999) can also achieve high profits through differentiation or focus (Porter 1979, 1980). Small firms avoid competing against large generalists by serving market niches (or peripheral markets, according to

\section{FIGURE 1 The Rule of Three}

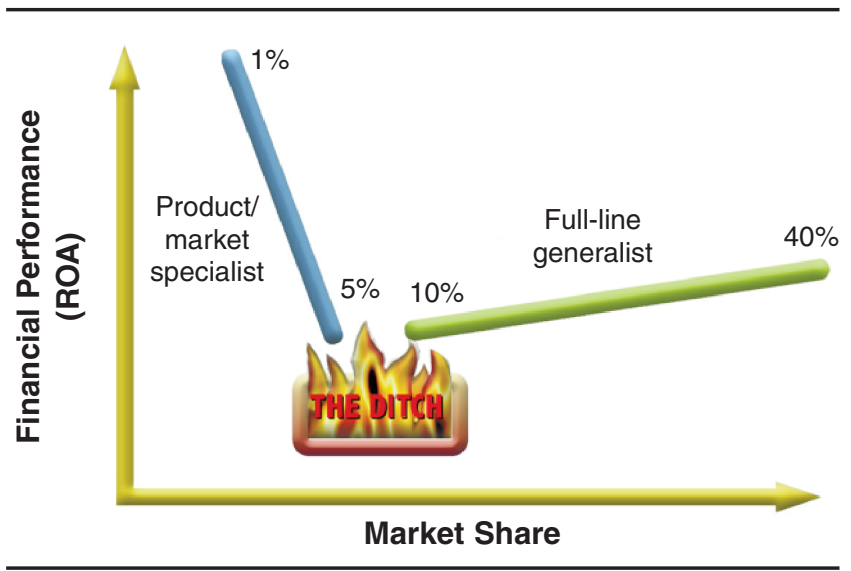

Notes: Reproduced with the authors' permission (Sheth and Sisodia 2002, p. 4). 
resource partitioning theory) that are less accessible to large firms and thus operate in separate competitive arenas (Carroll 1985; Caves and Porter 1977; Nooteboom 1994; Porter 1979; Swaminathan 2001). Customer loyalty toward specialists also makes it difficult for generalists to imitate specialists and replicate their success. For example, in general, early efforts by Anheuser-Busch to replicate the success of microbreweries failed, even though the firm possesses the necessary resources and technology (Swaminathan 2001). Thus, small firms may often achieve high price-cost margins and high overall profitability (Audretsch, Prince, and Thurik 1999).

Sheth and Sisodia (2002) conceptualize firms that possess 5\%-10\% share of the market as being in "the ditch" because such firms compete without either the benefit of the efficiencies that can come from greater scale/market share or the effectiveness of a focus strategy. Specialists have a deep understanding of one or a few segments, whereas generalists have a broad knowledge of the entire industry. "Ditch dwellers" have neither. These tend to be small firms that have overgrown their niches (e.g., People Express) or undersized full-line companies (e.g., Continental Airlines).

Resource partitioning theory makes an equivalent argument: Larger generalists gain advantages as a result of economies of scale, such that the overall losers of this competitive process are typically smaller generalists (Peli and Nooteboom 1999). "When the large organizations enter, those in the middle of the size distribution are trapped. Whatever strategy they adopt to fight off the challenge of the larger form makes them more vulnerable in competition with small organizations, and vice versa. That is, at least in a stable environment the two ends of the size distribution ought to outcompete in the middle" (Hannan and Freeman 1977, p. 946). Consequently, firms "stuck in the middle" (Porter 1980) or, equivalently, "in the ditch" (Sheth and Sisodia 2002) lack strategic focus and have more limited opportunities to achieve high levels of profitability.

Although the expectation that firms in the ditch will perform worse than smaller-share rivals is counter to evidence from most PIMS-based and industrial organization studies, it garners some empirical support. For example, Caves and Porter (1977), Hamermesh, Anderson, and Harris (1978), and Woo and Cooper (1982) find that smaller-share competitors can be equally or more profitable than larger-share rivals, while midshare firms may perform the worst (Dobrev and Carroll 2003; Schwalbach 1991), suggesting that the relationship between market share and profitability is nonmonotonic. Similarly, in a study of Dutch daily newspapers, Boone, Carroll, and Van Witteloostuijn (2004) show that both generalists and specialists had higher growth and profitability than those stuck in the middle. Amburgey, Dacin, and Kelly's (1994) study of credit unions reveals a "danger zone" of intermediate firm size in which the risks of failure (or merger) are significantly greater than they are for either very small or large firms, resulting in an industry bifurcation into these two size classes of competitors. Thus:

$\mathrm{H}_{4}$ : Generalists perform better than firms in the ditch (i.e., firms with intermediate market share).
$\mathrm{H}_{5}$ : Specialists perform better than firms in the ditch (i.e., firms with intermediate market share).

In the economics literature, $40 \%$ market share is a generally accepted threshold for what is termed a "dominant firm" (Scherer and Ross 1990; Shepherd 1990). Notably, Sheth and Sisodia (2002) argue that generalists lose their advantages from scale and scope when they achieve this level of dominance. The diseconomy effect, along with additional regulation and antitrust scrutiny, is likely to become evident beyond $40 \%$ market share and lead to diminished firm performance (Geroski 1987; Sheth and Sisodia 2002). Market leaders may also price aggressively to discourage challengers, which may hinder their profitability (Caves, Fortunato, and Ghemawat 1984). Resource partitioning scholars have also noted that surviving generalists tend to become larger and more general over time, an inertia that would be expected eventually to drag down ratio measures of performance (e.g., ROA, return on sales [ROS]) of the top generalist (Carroll and Hannan 2000).

The notion that dominant firms may experience lower performance contradicts the market share $\rightarrow$ performance dictum reinforced by numerous PIMS-based empirical studies (e.g., Buzzell and Gale 1987). Bloom and Kotler (1975, p. 65) specifically criticize PIMS-based research findings in this regard, noting that the approach "does not reveal whether profitability eventually turns down at very high market-share levels;... therefore, the behavior of ROI in response to still higher market shares is undisclosed." Notably, a few empirical studies have also reported that high market share might hurt performance. For example, Schwalbach (1991) observes that large-share competitors (those with greater than 35\%-65\% market share, depending on industry) are frequently less profitable than slightly smaller rivals, indicating that market share may not contribute to profitability beyond a certain size. Similarly, Boulding and Staelin (1990, 1993) find that diminished performance (i.e., increasing costs) often accompanies very large market share, and Armstrong and Collopy (1996) find that market share orientation shrinks profits.

Alternative explanations have been advanced as to why market share above a certain level may lead to lower firm performance. For example, Boulding and Staelin (1993) suggest that market share can be conceptualized as a measure of organizational success relative to aspiration level, such that "fat and happy" firms are no longer competitively efficient. In other words, as market share reaches or surpasses a firm's aspirational level, "success breeds complacency" (Boulding and Staelin 1993, p. 147; Drucker 1982). These aspirations may also be dulled at some level by managerial concerns over competitive reactions or antitrust issues. There is also evidence that customer satisfaction may decrease with high market share (Anderson, Fornell, and Lehmann 1994; Fornell 1995), which would then depress profitability (for other disadvantages, see Table 1).

Conversely, very small specialists with less than $1 \%$ market share are considered too small to generate substantial brand, customer, or channel equity (Sheth and Sisodia 2002). They also tend to lack the ability and resources to commercialize innovation or serve as change agents on 
their own. Typically, the lucky few that come up with a promising breakthrough are either acquired and subsumed or grow to become successful and legitimate specialists (with more than 1\% share). Microfirms dominate the economy in numbers but not in impact or superior performance (Aldrich 1999). For example, lifestyle firms would fall under this category. Thus:

$\mathrm{H}_{6}$ : Generalists with excessive (i.e., $>40 \%$ ) market share perform worse than other generalists.

$\mathrm{H}_{7}$ : Specialists with insufficient (i.e., $<1 \%$ ) market share perform worse than other specialists.

\section{Data and Methodology}

We compiled the majority of the data for the study from three sources: Standard \& Poor's COMPUSTAT (Research Insight), the University of Chicago's Center for Research in Securities Prices (CRSP) database, and the U.S. Census Bureau. COMPUSTAT contains accounting data for all North American companies that file annual reports with the Securities and Exchange Commission (SEC). Firms with multiple business units/segments are required to file separate reports for each of these segments with the SEC. The initial data set consisted of information on the entire sample of U.S. firms and all their business units/segments for the years 1997 and 2002. These years represented the most recent U.S. economic census data available, and the only periods in which the North American Industry Classification System (NAICS) codes were used during data collection. We identified the industries by five-digit primary NAICS codes. We obtained aggregate sales figures for each NAICS code from the U.S. Census Bureau. Following the practice of similar studies in finance, we excluded from our sample firms with incomplete information in COMPUSTAT or CRSP databases as well as financial firms (because their accounting-based performance measures do not lend themselves to the same interpretation as nonfinancial [industrial] firms [Ritter 1991]).

To reiterate, Sheth and Sisodia (2002) define generalists as firms with $\geq 10 \%$ market share (i.e., "critical mass" to benefit from economies of scale and scope), specialists as firms with $<5 \%$ market share, and those in the ditch as every firm in between. We followed their definitions to test the theory. However, taking other perspectives into consideration and to ensure robust and generalizable results, we specified and analyzed four additional specifications for the threshold dividing generalists from firms in the ditch: specifically, $12.5 \%, 15 \%, 17.5 \%$, and $20 \%$ share of the market (for rationale, see the Appendix). Subsequently, we classified industries that had exactly three generalists as R3 industries. We calculated market share as the total dollar sales of the firm (or the business unit for a diversified firm) divided by the total dollar sales in the firm's (or unit's) primary NAICS code.

We used two major performance measures in the analyses: operating return on assets (oROA) and annual cumulative abnormal return (CAR). We calculated oROA as the operating income of the firm or unit divided by the total identifiable assets of the firm or unit. We used oROA instead of net ROA to retain the data from firms with separate lines of businesses. For firms with multiple business units, it is not possible to calculate reliable net earnings measures for a given unit. Furthermore, operating measures are much more meaningful in measuring the effects of market share because these do not take into account any gains from off-balance sheet accounting and financial investments.

The performance effects of market share and industry structure should be relatively stable and enduring. Therefore, we also examined the forward-looking three-year averages of operating performance for the firms in our sample. We used the three fiscal years following 1997 (i.e., 1998-2000) and 2002 (i.e., 2003-2005) in our calculations.

Next, we analyzed the stock market performance of the firms in our sample to determine whether variations in operating profitability are considered in the valuation by financial markets. We obtained the monthly return data used in CAR calculations from CRSP. We excluded from this analysis firms or business units that did not have stock data. We calculated stock market performance as the mean annual CAR during fiscal years 1997 and 2002 and for the three-year (36-month) period following the end of fiscal years 1997 and 2002. We calculated the annualized CAR for security $\mathrm{j}$ as follows:

$$
\mathrm{CAR}_{\mathrm{j}}=\left[\prod_{\mathrm{t}=1}^{36}\left(\mathrm{AR}_{\mathrm{jt}}+1\right)\right]^{\frac{1}{3}}-1,
$$

where AR represents the abnormal return during month $t$ for security $\mathrm{j}$. Abnormal return is the excess return earned by a stock above the expected risk-adjusted return in a given period based on the market model. In other words, abnormal return is

$$
\mathrm{AR}_{\mathrm{jt}}=\mathrm{R}_{\mathrm{jt}}-\left(\alpha_{\mathrm{j}}+\beta_{\mathrm{j}} \mathrm{R}_{\mathrm{Mt}}\right)
$$

where $R_{j t}$ is the actual observed return on stock $j$ during month $\mathrm{t}$. The term in parentheses represents the riskadjusted expected return for stock $\mathrm{j}$ during month $\mathrm{t}$. We estimated this systematic risk factor $\beta$ using the historical returns on stock $\mathrm{j}$ during the $[-120,-12]$-month period around the abnormal return calculation. We estimated beta using the following regression model:

$$
R_{j t}=\alpha_{j}+\beta_{j} R_{M t}+\varepsilon_{j t},
$$

where $\mathrm{R}_{\mathrm{Mt}}$ is the return during month $\mathrm{t}$ on the CRSP valueweighted index.

Finally, note that the Rule of Three is applicable to mature industries (Sheth and Sisodia 2002). Emerging markets (e.g., satellite radio) are not expected to support its hypotheses, because they have not yet reached a state of competitive (dynamic) equilibrium. Therefore, we excluded all industries that were younger than 15 years from the sample. We calculated industry age as the maximum age of the firms in the NAICS code (we obtained firm age from http://bear.cba.ufl.edu/ritter/ipodata.htm). The resultant sample consisted of 1369 firms from 152 industries for 1997 and 1108 firms from 165 industries for 2002.

We used simple t-tests for univariate tests. In the regression models, we used firm size and market-to-book ratios as 
control variables for operating and stock market performance, following the practice in finance research (e.g., Barber and Lyon 1997). We incorporated market concentration, calculated as the sum of the top four firms' market shares, in model development to account for competitive intensity. To minimize the effects of composite variable bias (Farris, Parry, and Ailawadi 1992), we used number of employees as a proxy for firm size because both assets and sales are part of the dependent variable calculation. We used ordinary least squares models with White heteroskedasticitycorrected standard errors in the regression analyses. We included dummy variables for each firm to control for any firm-specific (unobserved) effects in these regressions. We do not report coefficients for the dummy variables because of space constraints. Alternative calculation methods and use of operating ROS (oROS) as a performance measure revealed qualitatively the same results (for additional robustness checks, see the Appendix).

\section{Results and Discussion}

Industry convergence to three generalists is a central axiom of the Rule of Three. As Figure 2 shows, the mode for the frequency distribution of the number of generalists is consistently three (i.e., 62 industries representing $41 \%$ of the 1997 sample and 74 industries representing $45 \%$ of the 2002 sample). We conducted sensitivity analyses to ensure that the mode three is not merely an outcome of the way we operationalized generalists. The mode for the number of generalists remained three for alternative boundary cutoff points at every percentage point above $7 \%$ and below $22 \%$ market share, suggesting that the finding is robust. In addition, plots for industry age versus the number of generalists (unreported) displayed a pattern of industry convergence to three generalists over time. Therefore, we were able to gar- ner support both for the evolutionary logic of the Rule of Three and for $\mathrm{H}_{1}$.

As Table 2 shows, $\mathrm{H}_{2}$ is supported because $\mathrm{R} 3$ industries performed significantly better than industries with more generalists for every performance measure for both years (the only exception is annual CAR for 2002, which is significant at the .10 level). (Operating) ROA, the main performance measure advocated by the Rule of Three, is highly significant for both years. For example, the R3 industry oROA average is $16.52 \%$ for 1997 , whereas industries with more generalists average only $5.42 \%$.

Conversely, Table 2 also shows that R3 industries also performed significantly better than industries with fewer generalists for all but one performance measure. For example, the R3 industry oROA average is $15.1 \%$ for 2002, whereas industries with fewer generalists average only $4.89 \%$. The only exception is the annual CAR measure. We have been consistently conservative in our CAR measurements (see the Appendix), which may have diminished the significance of our CAR-related test results. Nevertheless, the annual CAR results are significant for both 1997 and 2002 at the .10 level, which is a widely reported confidence level for CAR findings in finance and marketing literature (e.g., Adrian and Rosenberg 2008; Luo and Homburg 2008). Therefore, in general, we find support for $\mathrm{H}_{3}$. Further t-tests (unreported) comparing R3 industry performance with industries specifically with two (G2) and/or four (G4) generalists also verified the reported findings. In all tests, firms in R3 industries performed significantly better than those from alternative industry structures.

In Table 3, we present regression analyses that provide further support for our findings. The main variable of interest in these regressions is the R3 dummy variable, which takes the value of one if the firm is in an R3 industry (i.e., an industry with exactly three generalists). The coefficients

FIGURE 2

Frequency Distribution of Generalists (with 10\% Market Share Threshold)

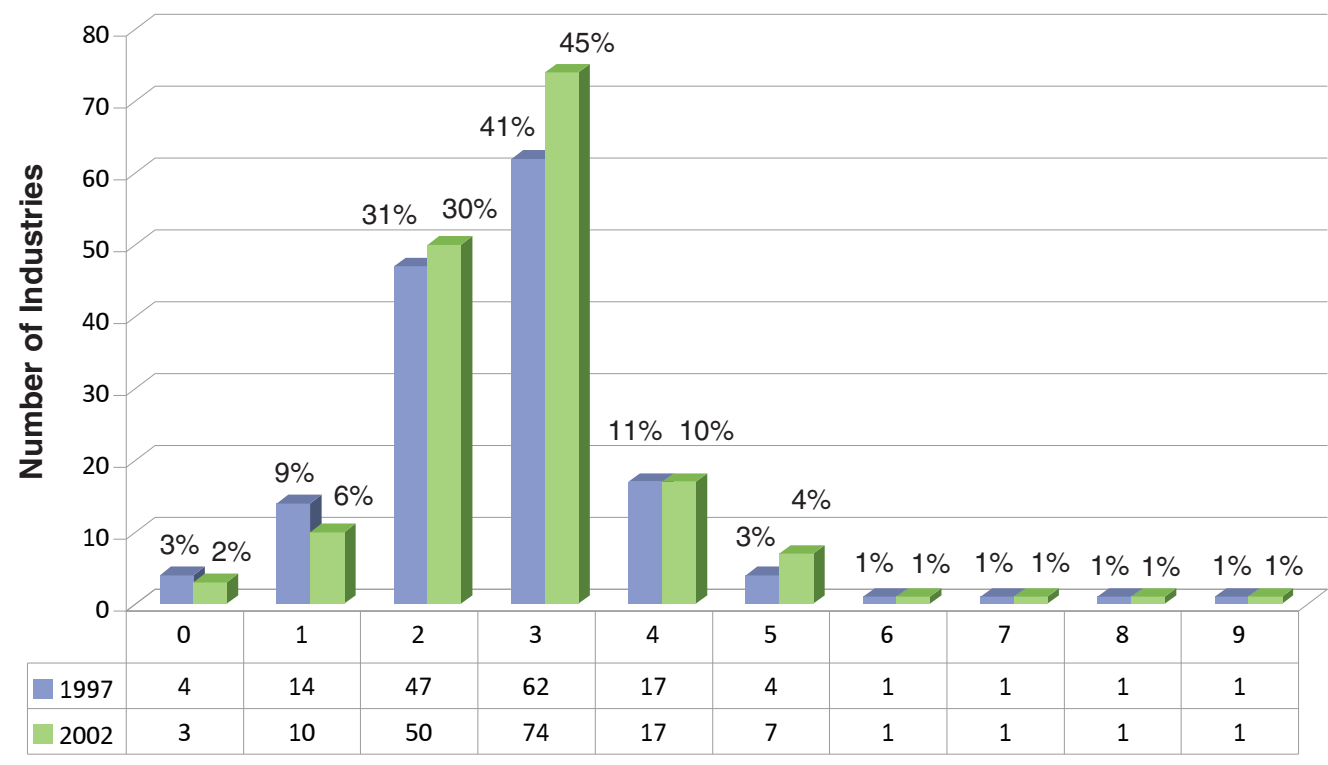

Number of Generalists in Industry 
TABLE 2

Mean Performance of R3 Industries Versus Industries with More and Fewer Than Three Generalists

\begin{tabular}{|c|c|c|c|c|c|}
\hline \multicolumn{6}{|c|}{ A: 1997 Sample } \\
\hline & $\begin{array}{c}<3 \text { Generalists } \\
(\mathrm{G} 0,1,2)\end{array}$ & $\begin{array}{c}\text { Difference } \\
\text { (R3 - G0, 1, 2) } \\
\text { t-Statistic }\end{array}$ & $\begin{array}{c}\text { R3 } \\
\text { Industries }\end{array}$ & $\begin{array}{c}\text { Difference } \\
\text { (R3 - G4, 5+) } \\
\text { t-Statistic }\end{array}$ & $\begin{array}{c}\text { >3 Generalists } \\
\text { (G4, 5+) }\end{array}$ \\
\hline oROA (\%) & 5.522 & $3.14^{\star \star \star}$ & 16.520 & $4.15^{\star \star \star}$ & 5.424 \\
\hline Three-year oROA (\%) & 8.572 & $2.05^{\star \star}$ & 14.029 & $3.01^{\star \star \star}$ & 7.732 \\
\hline CAR $(\%)$ & 2.054 & $1.89^{*}$ & 3.566 & $2.27^{\star \star}$ & 2.020 \\
\hline Three-year CAR (\%) & 2.973 & $2.03^{\star \star}$ & 4.518 & $2.15^{\star \star}$ & 2.821 \\
\hline Price-earnings ratio & 14.095 & $2.22^{\star \star}$ & 21.504 & $2.46^{\star \star \star}$ & 16.827 \\
\hline \multicolumn{6}{|c|}{ B: 2002 Sample } \\
\hline & $\begin{array}{c}<3 \text { Generalists } \\
(\mathrm{G} 0,1,2)\end{array}$ & $\begin{array}{c}\text { Difference } \\
\text { (R3 - G0, 1, 2) } \\
\text { t-Statistic }\end{array}$ & $\begin{array}{c}\text { R3 } \\
\text { Industries }\end{array}$ & $\begin{array}{c}\text { Difference } \\
\text { (R3 - G4, 5+) } \\
\text { t-Statistic }\end{array}$ & $\begin{array}{c}\text { >3 Generalists } \\
\text { (G4, 5+) }\end{array}$ \\
\hline oROA (\%) & 4.887 & $2.24^{\star \star}$ & 15.102 & $3.15^{\star \star \star}$ & 6.982 \\
\hline Three-year oROA (\%) & 6.528 & $2.18^{\star \star}$ & 11.527 & $2.19^{\star \star}$ & 5.956 \\
\hline $\operatorname{CAR}(\%)$ & 1.870 & $1.74^{\star}$ & 2.211 & $1.88^{*}$ & 1.197 \\
\hline Three-year CAR (\%) & 2.206 & $2.10^{\star \star}$ & 3.860 & $2.00^{* *}$ & 1.891 \\
\hline Price-earnings ratio & 16.340 & $2.17^{\star \star}$ & 19.730 & $2.21^{* *}$ & 14.840 \\
\hline $\begin{array}{l}{ }^{{ }^{*} p}<.10 . \\
{ }^{*} p<.05 . \\
\text { Notes: G0, G1, G2, and } \mathrm{G} \\
\quad \text { generalists. }\end{array}$ & ote industries with & 1,2 , and 4 genera & espectively, & denotes industr & with 5 or more \\
\hline
\end{tabular}

for the R3 dummy are consistently positive and significant for all performance measures, indicating enhanced performance due to the presence of the R3 structure. R3 coefficients are also consistently significantly higher than those for two- or four-generalist industries for both 1997 and 2002. Furthermore, the R3 effect persists despite the inclusion of market concentration and market share. Therefore, the R3 effect cannot be fully accounted for by any of these variables or the traditional explanations they represent (i.e., market power and efficiency). R3 interactions with market share and with market concentration are both positive and significant, indicating complex moderation effects between R3 and performance. (Moreover, these synergistic R3 effects tend to exceed those from other industry structures.) It appears that the R3 effect helps firms capture many benefits of efficiency and market power but also provides them with a structural advantage that goes beyond these basic explanations. Although beyond the scope of our current effort, future inquiry of these effects is warranted.

The Rule of Three theory suggests a nonmonotonic "hockey stick" relationship between market share and performance (see Figure 1). Similarly, Porter (1980) suggests a U-shaped relationship between market share and profitability. To account for potential nonlinearity in the relationship, we included the square of the market share term in the regressions. In general, the coefficients for the squared market share term are positive and significant, implying a nonmonotonic convex function, which is consistent with the Rule of Three. The existence of such a relationship when fitting linear models could result in confounded (and, thus, nonsignificant) findings. This might explain why some researchers have found little or no empirical relationship between market share and performance. The variance inflation factor values for the regressions were all below the recommended benchmark of 10, indicating that multicollinearity is not an issue (Neter et al. 1996, p. 387).

In Table 4, we present the t-tests that compare the performance of generalist firms with those in the ditch. In general, the results are more significant with 1997 data (the price-earnings ratio is the only performance measure that is significant when using the 2002 sample). This may be because of the postrecession slump included in the 2002 data and/or imply that the ditch range may benefit from further delineation in future research. Still, $\mathrm{H}_{4}$ is supported by four of the five tests (including oROA) for the 1997 sample, implying that generalist firms are typically more profitable than those in the ditch. For example, average oROA for the generalists in 1997 is $10.58 \%$, whereas the average oROA for ditch dwellers is $6.3 \%$. This finding would also be expected by neoclassical economic theory.

In Table 4, we also present the t-tests of the performance metrics for specialist firms versus those "in the ditch." Specialists significantly outperform the firms in the ditch for all measures (with the exception of oROA for 2002). Among others, specialists have higher price-earnings $(\mathrm{P} / \mathrm{E})$ ratios (P/E of 22.54 for 2002) and better stock market performance than firms in the ditch (P/E of 13.95 for 2002). The implication is that the market may actually discount the stock value of firms in the ditch because of some anticipation of problems for these firms and reflect these in their future growth prospects, as measured by price-earnings ratios. These concerns are also potentially reflected in the 
TABLE 3

Effects of Industry Structure on Firm Performance

\begin{tabular}{|c|c|c|c|c|c|c|c|c|}
\hline \multirow[b]{2}{*}{ Dependent Variable } & \multicolumn{4}{|c|}{1997 Sample } & \multicolumn{4}{|c|}{2002 Sample } \\
\hline & OROA & Three-Year oROA & CAR & Three-Year CAR & OROA & Three-Year oROA & CAR & Three-Year CAR \\
\hline \multirow[t]{2}{*}{ Intercept } & .050 & .063 & .001 & .001 & .003 & .003 & .0005 & .0002 \\
\hline & $(1.26)$ & $(1.32)$ & $(1.02)$ & $(1.04)$ & (1.09) & $(1.07)$ & $(1.08)$ & $(1.10)$ \\
\hline \multirow[t]{2}{*}{ Market share (MS) } & $.395^{\star}$ & $.431^{\star \star}$ & $.003^{\star}$ & $.004^{\star}$ & $.516^{\star}$ & $.581^{\star}$ & $.008^{\star}$ & $.010^{*}$ \\
\hline & $(1.77)$ & $(2.02)$ & $(1.73)$ & $(1.77)$ & $(1.80)$ & $(1.72)$ & $(1.77)$ & $(1.82)$ \\
\hline \multirow[t]{2}{*}{ MS2 } & $.564^{\star \star}$ & $.599^{\star \star \star}$ & $.006^{\star}$ & $.005^{\star}$ & $.589^{\star \star}$ & $.796^{\star \star}$ & $.004^{\star \star}$ & $.007^{\star \star}$ \\
\hline & $(2.28)$ & (3.02) & $(1.84)$ & $(1.83)$ & $(2.21)$ & $(2.24)$ & (2.03) & $(2.06)$ \\
\hline \multirow[t]{2}{*}{ Number of employees } & $-.0061^{*}$ & $-.004^{\star}$ & $-.0004^{*}$ & $-.0005^{\star}$ & $-.005^{\star}$ & $-.005^{\star}$ & $-.0002^{*}$ & $-.0003^{\star}$ \\
\hline & $(-1.87)$ & $(-1.88)$ & $(-1.92)$ & $(-1.90)$ & $(-1.79)$ & $(-1.81)$ & $(-1.84)$ & $(-1.92)$ \\
\hline \multirow[t]{2}{*}{ Market-to-book ratio } & $.003^{\star \star}$ & $.006^{\star \star}$ & $.0003^{\star \star}$ & $.0005^{\star \star}$ & $.002^{\star *}$ & $.002^{\star \star}$ & $.0004^{\star *}$ & $.0005^{\star \star}$ \\
\hline & $(2.04)$ & $(2.13)$ & $(2.06)$ & $(2.08)$ & $(1.99)$ & $(2.03)$ & $(2.18)$ & $(2.17)$ \\
\hline \multirow[t]{2}{*}{ Firm age } & .001 & .001 & .0002 & .0003 & .001 & .001 & .001 & .001 \\
\hline & $(1.05)$ & $(1.25)$ & $(.78)$ & $(.79)$ & $(1.38)$ & $(1.35)$ & $(1.23)$ & $(1.24)$ \\
\hline \multirow[t]{2}{*}{ Market concentration (MC) } & $.251^{\star *}$ & $.352^{\star *}$ & $.003^{\star}$ & $.004^{\star}$ & $.361^{\star *}$ & $.416^{\star *}$ & $.002^{*}$ & $.003^{\star}$ \\
\hline & $(1.99)$ & $(2.04)$ & $(1.87)$ & $(1.93)$ & $(2.04)$ & $(2.12)$ & $(1.77)$ & $(1.74)$ \\
\hline \multirow[t]{2}{*}{ One generalist (G1) } & -.053 & -.081 & -.004 & -.003 & -.051 & -.077 & -.001 & -.003 \\
\hline & $(-1.40)$ & $(-1.56)$ & $(-1.21)$ & $(1.24)$ & $(-1.14)$ & $(-1.16)$ & $(-1.03)$ & $(-1.12)$ \\
\hline \multirow[t]{2}{*}{ Two generalists (G2) } & $.101^{*}$ & $.181^{\star \star}$ & $.006^{\star}$ & $.005^{\star}$ & $.113^{\star \star}$ & $.109^{\star \star}$ & $.004^{\star}$ & $.006^{\star}$ \\
\hline & $(1.88)$ & $(2.10)$ & $(1.75)$ & $(1.77)$ & $(2.16)$ & $(2.14)$ & $(1.86)$ & $(1.84)$ \\
\hline \multirow[t]{2}{*}{ R3 } & $.130^{\star \star}$ & $.319^{\star \star \star}$ & $.009^{\star *}$ & $.011^{\star *}$ & $.136^{\star \star \star}$ & $.129^{\star \star \star}$ & $.007^{\star \star}$ & $.008^{\star \star}$ \\
\hline & $(2.03)$ & $(4.01)$ & (2.09) & (2.17) & (3.77) & (3.21) & $(2.02)$ & $(2.05)$ \\
\hline \multirow[t]{2}{*}{ Four generalists (G4) } & .055 & .084 & .002 & .003 & $.088^{\star \star}$ & $.071^{\star}$ & .001 & .001 \\
\hline & $(1.62)$ & $(1.67)$ & $(1.46)$ & $(1.51)$ & $(1.98)$ & $(1.82)$ & $(1.52)$ & $(1.56)$ \\
\hline \multirow[t]{2}{*}{ Five+ generalists (G5+) } & .032 & .042 & .001 & .002 & .020 & .033 & .001 & .001 \\
\hline & $(1.36)$ & $(1.35)$ & $(1.19)$ & $(1.21)$ & $(1.05)$ & $(1.28)$ & $(1.18)$ & $(1.17)$ \\
\hline \multirow[t]{2}{*}{$\mathrm{G} 1 \times \mathrm{MS}$} & $.013^{\star}$ & $.014^{\star}$ & $.007^{\star}$ & $.009^{\star}$ & $.012^{\star}$ & $.013^{\star}$ & $.007^{\star}$ & $.006^{\star}$ \\
\hline & $(1.81)$ & $(1.90)$ & $(1.93)$ & $(1.94)$ & $(1.79)$ & $(1.82)$ & (1.93) & (1.95) \\
\hline \multirow[t]{2}{*}{$\mathrm{G} 2 \times \mathrm{MS}$} & $.025^{\star *}$ & $.021^{\star *}$ & $.001^{*}$ & $.001^{*}$ & $.034^{\star}$ & $.035^{\star *}$ & .0003 & .0004 \\
\hline & (2.02) & $(2.12)$ & $(1.73)$ & $(1.74)$ & $(1.78)$ & $(2.04)$ & (1.58) & (1.59) \\
\hline \multirow[t]{2}{*}{$\mathbf{R} 3 \times \mathbf{M S}$} & $.049^{\star * *}$ & $.041^{\star \star \star}$ & $.004^{\star \star}$ & $.005^{\star \star}$ & $.066^{\star \star}$ & $.037^{\star \star *}$ & $.001^{\star \star}$ & $.001^{\star}$ \\
\hline & (2.63) & (2.67) & $(2.05)$ & $(2.04)$ & $(2.01)$ & $(2.45)$ & (1.97) & (.199) \\
\hline \multirow[t]{2}{*}{$\mathrm{G} 4 \times \mathrm{MS}$} & $.025^{\star}$ & $.021^{\star}$ & .001 & $.001^{\star}$ & .022 & $.015^{\star}$ & .0004 & .0003 \\
\hline & $(1.90)$ & $(1.74)$ & (1.69) & $(1.72)$ & (1.58) & (1.93) & $(1.43)$ & (1.52) \\
\hline \multirow[t]{2}{*}{$\mathrm{G} 5 \times \mathrm{MS}$} & .008 & .006 & .001 & .001 & .006 & .007 & .001 & .001 \\
\hline & (1.67) & $(1.41)$ & $(1.21)$ & $(1.23)$ & (1.65) & $(1.48)$ & (1.34) & $(1.41)$ \\
\hline \multirow[t]{2}{*}{$\mathrm{G} 1 \times \mathrm{MC}$} & $.092^{\star}$ & $.085^{\star}$ & .001 & $.001^{\star}$ & $.090^{\star}$ & $.065^{\star}$ & .001 & $.001^{\star}$ \\
\hline & $(1.94)$ & $(1.78)$ & $(1.66)$ & $(1.74)$ & $(1.90)$ & $(1.74)$ & (1.66) & $(1.74)$ \\
\hline \multirow[t]{2}{*}{$\mathrm{G} 2 \times \mathrm{MC}$} & $.058^{\star \star}$ & $.062^{\star \star}$ & $.002^{\star}$ & $.003^{\star}$ & $.031^{\star \star}$ & $.052^{\star}$ & $.001^{\star}$ & $.001^{\star}$ \\
\hline & (1.97) & (2.01) & $(1.74)$ & $(1.81)$ & (1.99) & $(1.76)$ & $(1.80)$ & (1.83) \\
\hline \multirow[t]{2}{*}{$\mathrm{R} 3 \times \mathrm{MC}$} & $.081^{\star \star}$ & $.093^{\star \star}$ & $.008^{\star *}$ & $.008^{\star \star}$ & $.138^{\star \star \star}$ & $.147^{\star \star}$ & $.001^{\star *}$ & $.001^{\star}$ \\
\hline & $(2.06)$ & $(2.10)$ & (2.18) & $(2.21)$ & (3.31) & (2.22) & (1.98) & (1.99) \\
\hline
\end{tabular}


TABLE 4

Mean Performance of Generalists and Specialists Versus Firms in the Ditch

\begin{tabular}{|c|c|c|c|c|c|}
\hline \multicolumn{6}{|c|}{ A: 1997 Sample } \\
\hline & & $\begin{array}{c}\text { Difference } \\
\text { (Generalist - Ditch) }\end{array}$ & & $\begin{array}{c}\text { Difference } \\
\text { (Specialist - Ditch) }\end{array}$ & \\
\hline & Generalist & t-Statistic & Ditch & t-Statistic & Specialist \\
\hline oROA (\%) & 10.577 & $2.55^{\star \star \star}$ & 6.290 & $2.18^{\star \star}$ & 13.577 \\
\hline Three-year oROA (\%) & 9.011 & $1.82^{*}$ & 7.847 & $2.36^{\star \star \star}$ & 12.678 \\
\hline CAR $(\%)$ & 3.568 & $1.98^{* *}$ & 1.990 & $2.16^{\star \star}$ & 3.719 \\
\hline Three-year CAR (\%) & 4.529 & $2.01^{\star \star}$ & 2.366 & $2.07^{\star \star}$ & 4.763 \\
\hline Price-earnings ratio & 20.77 & $3.19^{\star \star \star}$ & 16.81 & $2.26^{\star *}$ & 21.54 \\
\hline \multicolumn{6}{|c|}{ B: 2002 Sample } \\
\hline & & $\begin{array}{c}\text { Difference } \\
\text { (Generalist - Ditch) }\end{array}$ & & $\begin{array}{c}\text { Difference } \\
\text { (Specialist - Ditch) }\end{array}$ & \\
\hline & Generalist & t-Statistic & Ditch & t-Statistic & Specialist \\
\hline oROA (\%) & 12.425 & 1.23 & 11.762 & -1.25 & 10.609 \\
\hline Three-year oROA (\%) & 11.741 & 1.55 & 10.202 & $3.12^{* \star *}$ & 12.560 \\
\hline CAR $(\%)$ & 1.550 & $1.80^{*}$ & .674 & $2.03^{\star \star}$ & 1.797 \\
\hline Three-year CAR (\%) & 1.585 & $1.78^{\star}$ & .967 & $1.98^{* *}$ & 2.014 \\
\hline Price-earnings ratio & 18.74 & $1.92^{\star \star}$ & 13.95 & $2.83^{\star \star \star}$ & 22.54 \\
\hline
\end{tabular}

lower CARs for these firms. Overall, $\mathrm{H}_{5}$ is supported by nine of the ten performance tests.

In Table 5, we present the regression analyses that provide further support for the findings that firms in the ditch tend to underperform. The main variable of interest in this regression is the "ditch" dummy, which takes the value of 1 for firms with market share that is less than $10 \%$ but greater than or equal to $5 \%$. The ditch dummy is negative and significant for every performance measure. These results clearly indicate that the ditch represents a range of depressed profitability. Notably, the interaction between R3 and the ditch is positive and significant for three-year oROA, indicating that the R3 effect is more dominant and may mitigate the ditch penalty in the long run. That is, even the firms in the ditch may benefit from the formation of an R3 structure. We excluded market share measures, which served to define the ditch dummies, from this set of regression specifications. The variance inflation factor values for the regressions were all below the recommended benchmark of 10 , indicating that multicollinearity is not an issue (Neter et al. 1996, p. 387).

As Table 6, Panel A, shows, the results are significant for six of the ten measures of performance for $\mathrm{H}_{6}$, suggesting that firms with excessively large market share tend to underperform. However, there is no significant profitability difference between generalists with more than $40 \%$ market share and other generalists, as measured by oROA. Nevertheless, a longer-term orientation (examining forward-looking three-year averages of operating performance) reveals that generalists with more than $40 \%$ market share may perform worse than other generalists. For example, the 1997 average three-year oROA for generalists with more than $40 \%$ market share is $8.67 \%$, whereas it is $11 \%$ for other generalists.
Thus, the results are partially supportive of $\mathrm{H}_{6}$. In addition, regression analyses in Table 5 provide inferential support for $\mathrm{H}_{6}$. In these analyses, we employ a dummy variable that takes the value of 1 when the top firm of an industry has more than 40\% market share ("Number 1 firm MS > 40\%") and a dummy variable that takes the value of 1 when the top firm of an industry has less than or equal to $40 \%$ market share ("Number 1 firm MS $<40 \%$ "). The coefficients for the latter dummy are consistently positive and significant, in contrast to the former dummy variable. However, it is unlikely that a specific market share point of maximum profitability universally applies to all generalists. Rather, it might be possible to establish thresholds for each industry and then establish specific ranges for different industry groups. Thus, the $40 \%$ market share limit to performance should be considered in the spirit of a guideline rather than a rule.

Table 6, Panel B, shows that the specialists with less than $1 \%$ market share significantly underperform other specialists (i.e., those with 1\%-5\% market share) for all performance measures for both years. For example, the 1997 average oROA for specialists with less than $1 \%$ market share is only $3.58 \%$, whereas it is $21.87 \%$ for other specialists. Therefore, $\mathrm{H}_{7}$ is supported. Notably, the financial market seems to price in lower growth opportunities to these small-share firms, causing their stock market performance to be lower as well.

Finally, it is noteworthy that the support garnered for $\mathrm{H}_{6}$ and $\mathrm{H}_{7}$ renders our results for $\mathrm{H}_{4}$ and $\mathrm{H}_{5}$ all the more conservative. If we were to exclude generalists with more than $40 \%$ market share and specialists with less than $1 \%$ market share from the $\mathrm{H}_{4}$ and $\mathrm{H}_{5}$ analyses, respectively, the results for both tests would have been even stronger. We performed further univariate tests and regression analyses using five alternative lower boundary share measures for generalists 
TABLE 5

The Effects of Ditch Status on Firm Performance

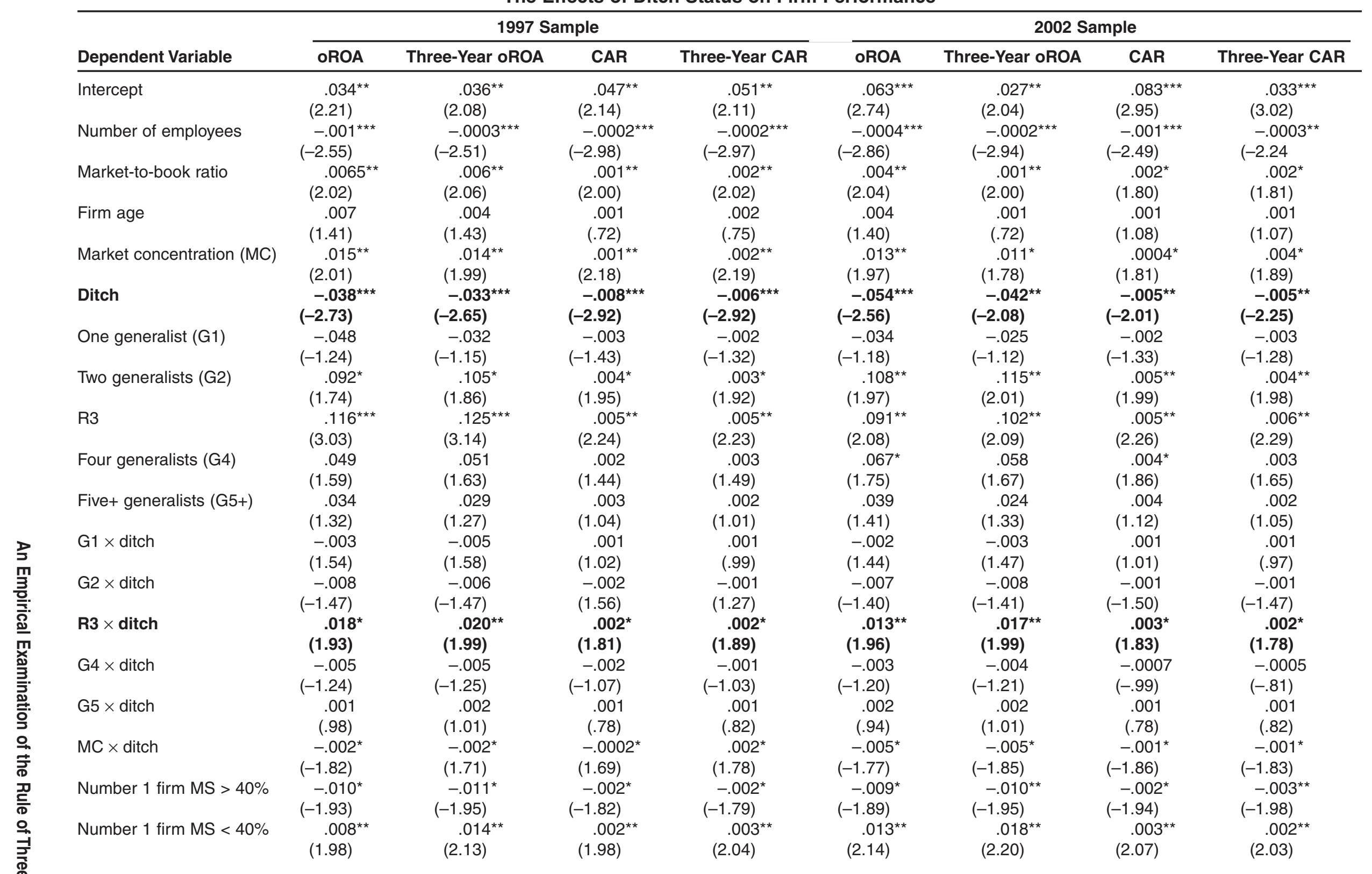


TABLE 5

Continued

\begin{tabular}{|c|c|c|c|c|c|c|c|c|}
\hline \multirow[b]{2}{*}{ Dependent Variable } & \multicolumn{4}{|c|}{1997 Sample } & \multicolumn{4}{|c|}{2002 Sample } \\
\hline & OROA & Three-Year oROA & CAR & Three-Year CAR & OROA & Three-Year oROA & CAR & Three-Year CAR \\
\hline Firm dummies & Yes & Yes & Yes & Yes & Yes & Yes & Yes & Yes \\
\hline $\mathrm{N}$ & 1369 & 1369 & 1064 & 1064 & 1108 & 1108 & 827 & 827 \\
\hline Adjusted $\mathrm{R}^{2}$ & .317 & .323 & .154 & .145 & .316 & .325 & .128 & .111 \\
\hline $\mathrm{F}$ & $8.14^{\star \star \star}$ & $9.07^{\star \star \star}$ & $4.59^{\star \star \star}$ & $3.96^{\star * \star}$ & $9.35^{\star \star \star}$ & $8.93^{\star \star \star}$ & $12.41^{\star \star \star}$ & $7.97^{\star \star \star}$ \\
\hline
\end{tabular}

${ }_{* \star *}^{*} p<0$

Notes: G0, G1, G2, and G4 denote industries with $0,1,2$, and 4 generalists, respectively, and G5+ denotes industries with 5 or more generalists. Bold entries are specifically related to hypothesis testing. 
TABLE 6

Mean Performance Effects of Excessive and Insufficient Market Share

\begin{tabular}{|c|c|c|c|c|c|c|}
\hline \multicolumn{7}{|c|}{ A: The Case of Excessive Market Share } \\
\hline & \multicolumn{3}{|c|}{1997 Sample } & \multicolumn{3}{|c|}{2002 Sample } \\
\hline & $\begin{array}{c}\text { Generalist } \\
\text { with Market } \\
\text { Share }>40 \%\end{array}$ & $\begin{array}{c}\text { Generalist } \\
\text { with Market } \\
\text { Share }<40 \%\end{array}$ & $\begin{array}{l}\text { Difference } \\
\text { t-Statistic }\end{array}$ & $\begin{array}{c}\text { Generalist } \\
\text { with Market } \\
\text { Share }>40 \%\end{array}$ & $\begin{array}{c}\text { Generalist } \\
\text { with Market } \\
\text { Share }<40 \%\end{array}$ & $\begin{array}{l}\text { Difference } \\
\text { t-Statistic }\end{array}$ \\
\hline oROA (\%) & 10.328 & 11.787 & -1.45 & 12.018 & 12.886 & -1.07 \\
\hline Three-year oROA (\%) & 8.670 & 11.008 & $-2.05^{\star \star}$ & 8.609 & 12.342 & $-1.79^{\star}$ \\
\hline CAR $(\%)$ & 3.054 & 4.571 & $-2.11^{\star *}$ & 1.001 & 1.106 & $-2.04^{\star \star}$ \\
\hline Three-year CAR (\%) & 4.034 & 5.182 & $-2.08^{\star \star}$ & 1.483 & 1.551 & $-1.81^{\star}$ \\
\hline Price-earnings ratio & 16.14 & 22.57 & $-3.15^{\star \star \star}$ & 9.14 & 16.21 & $-1.96^{\star \star}$ \\
\hline \multicolumn{7}{|c|}{ B: The Case of Insufficient Market Share } \\
\hline & \multicolumn{3}{|c|}{1997 Sample } & \multicolumn{3}{|c|}{2002 Sample } \\
\hline & $\begin{array}{c}\text { Generalist } \\
\text { with Market } \\
\text { Share > } 40 \%\end{array}$ & $\begin{array}{c}\text { Generalist } \\
\text { with Market } \\
\text { Share }<40 \%\end{array}$ & $\begin{array}{l}\text { Difference } \\
\text { t-Statistic }\end{array}$ & $\begin{array}{c}\text { Generalist } \\
\text { with Market } \\
\text { Share > } 40 \%\end{array}$ & $\begin{array}{c}\text { Generalist } \\
\text { with Market } \\
\text { Share }<40 \%\end{array}$ & $\begin{array}{l}\text { Difference } \\
\text { t-Statistic }\end{array}$ \\
\hline oROA (\%) & 3.581 & 21.872 & $-5.42^{\star \star \star}$ & 2.129 & 8.765 & $-4.64^{\star \star \star}$ \\
\hline Three-year oROA (\%) & 8.157 & 18.775 & $-4.05^{\star \star \star}$ & 4.8304 & 8.308 & $-2.49^{\star \star \star}$ \\
\hline CAR $(\%)$ & 2.051 & 4.215 & $-2.03^{\star \star}$ & .941 & 2.111 & $-2.21^{\star \star}$ \\
\hline Three-year CAR (\%) & 3.015 & 6.344 & $-2.57^{\star \star \star}$ & 1.242 & 2.458 & $-2.25^{\star \star}$ \\
\hline Price-earnings ratio & 15.32 & 34.90 & $-2.07^{\star \star}$ & 4.78 & 12.08 & $-3.04^{* * *}$ \\
\hline
\end{tabular}

for robustness. Only the key variables of these tests appear in Table 7, demonstrating further the robustness of our findings. Among others, the $15 \%$ cutoff seems to provide more significant findings and better fit for the R3 effect, with tolerable deterioration in the ditch effect. However, maximizing model fit may have a limiting effect on predictive power. We propose that further inquiry and delineation of each boundary is warranted.

\section{Managerial Implications}

In general, our findings support Sheth and Sisodia's (2002) Rule of Three theory at the expense of many prior studies on the market share-profitability relationship. We summarize the implications in three parts: for top management, for marketing, and for investors.

\section{Implications for Top Management}

Our generalizations regarding the relationship between market share and profitability do not preclude the existence of situational or conditional variables that might confound or even negate the sign of the relationship. Therefore, our findings should be accompanied by precaution against growth simply for the sake of growth. For example, using sales promotions to buy market share has been shown to hurt profitability even in the long run (Lodish and Mela 2007).

We found that generalists with excessive market share perform worse than their smaller counterparts in the long run. Similarly, our findings imply that specialists may jeopardize their financial performance and even end up in finan- cial distress in pursuit of market share. Thus, these firms may be better off by "outsourcing" some of their less- or unprofitable customers for potential gains in margins. In this regard, it should also be acknowledged that the right size for any firm is context specific (Prescott, Kohli, and Venkatraman 1986) and depends on the characteristics of the market, the state of the economy, technological conditions, strategic choice, and objectives.

When further growth appears to offer strategic benefits, this can be achieved organically over time (through marketing) or through merger-and-acquisition (M\&A) activity. Such M\&A activity can also boost overall industry profitability if it consolidates the number of generalists to (or toward) three. Top management of any firm must make a decision whether to become/remain a generalist (by drawing from a wide range of resources) or a specialist (through focus) in the firm's respective industry. It also appears that a generalist needs to exceed a market share threshold to become viable in the long run. However, the closer a firm is to the ditch and the more crowded the generalist space, the higher is the likelihood of falling into it. Full benefits of the Rule of Three should not be taken as given, even if a firm resides in an R3 industry. Top management must pay close attention to steer clear of the 5\%-10\% ditch area, or investors will be disappointed, and eventually the firm may become a target for M\&A (e.g., Kmart). Alternatively, a firm in the ditch can divest and emerge as a healthy specialist (e.g., IBM from a personal computer maker to a service provider).

Long gone are the times when the role of industry structure was preeminent in formal strategic planning (Mintz- 
TABLE 7

Robustness Tests Using Alternative Lower Boundary Share Measures for Generalists

\begin{tabular}{|c|c|c|c|c|c|c|c|c|c|c|}
\hline \multicolumn{11}{|c|}{ A: Univariate Tests } \\
\hline \multirow{2}{*}{$\begin{array}{l}\text { Generalist } \\
\text { Share Cutoff } \\
\text { Year }\end{array}$} & \multicolumn{2}{|c|}{$10 \%$} & \multicolumn{2}{|c|}{$12.5 \%$} & \multicolumn{2}{|c|}{$15 \%$} & \multicolumn{2}{|c|}{$17.5 \%$} & \multicolumn{2}{|c|}{$20 \%$} \\
\hline & 1997 & 2002 & 1997 & 2002 & 1997 & 2002 & 1997 & 2002 & 1997 & 2002 \\
\hline \multicolumn{11}{|c|}{ Difference in oROA } \\
\hline $\mathrm{R} 3-\mathrm{G} 0,1,2$ & $\begin{array}{l}11.298^{\star \star \star} \\
(3.14)\end{array}$ & $\begin{array}{l}10.215^{\star *} \\
(2.24)\end{array}$ & $\begin{array}{l}11.542^{\star \star \star} \\
(3.11)\end{array}$ & $\begin{array}{l}9.016^{\star \star} \\
(2.09)\end{array}$ & $\begin{array}{l}11.600^{\star \star \star} \\
(3.09)\end{array}$ & $\begin{array}{l}8.694^{\star * *} \\
(3.10)\end{array}$ & $\begin{array}{l}7.564^{\star *} \\
(2.18)\end{array}$ & $\begin{array}{l}4.152^{*} \\
(1.94)\end{array}$ & $\begin{array}{c}3.037 \\
(1.65)\end{array}$ & $\begin{array}{c}1.644 \\
(1.66)\end{array}$ \\
\hline R3 - G4, 5+ & $\begin{array}{l}11.096^{\star \star \star} \\
(4.15)\end{array}$ & $\begin{array}{l}8.12^{\star \star \star} \\
(3.15)\end{array}$ & $\begin{array}{l}11.251^{\star \star \star} \\
(4.05)\end{array}$ & $\begin{array}{l}8.164^{\star \star \star} \\
(2.31)\end{array}$ & $\begin{array}{l}11.38^{\star \star \star} \\
(4.88)\end{array}$ & $\begin{array}{l}9.592^{\star \star \star} \\
(2.61)\end{array}$ & $\begin{array}{l}5.483^{\star} \\
(1.83)\end{array}$ & $\begin{array}{l}6.140^{\star \star} \\
(2.04)\end{array}$ & $\begin{array}{c}3.33^{*} \\
(1.71)\end{array}$ & $\begin{array}{l}2.342^{*} \\
(1.69)\end{array}$ \\
\hline Generalist - ditch & $\begin{array}{l}4.287^{\star \star \star} \\
(2.55)\end{array}$ & $\begin{array}{r}.663 \\
(1.23)\end{array}$ & $\begin{array}{l}5.148^{\star \star *} \\
(2.52)\end{array}$ & $\begin{array}{l}1.678^{\star} \\
(1.76)\end{array}$ & $\begin{array}{l}7.334^{\star \star *} \\
(2.68)\end{array}$ & $\begin{array}{l}3.11^{*} \\
(1.82)\end{array}$ & $\begin{array}{l}5.148^{\star *} \\
(2.06)\end{array}$ & $\begin{array}{l}2.741^{\star} \\
(1.70)\end{array}$ & $\begin{array}{l}3.368^{*} \\
(1.70)\end{array}$ & $\begin{array}{c}1.32 \\
(1.60)\end{array}$ \\
\hline Specialist - ditch & $\begin{array}{l}7.287^{\star *} \\
(2.18)\end{array}$ & $\begin{array}{l}-1.153 \\
(-1.25)\end{array}$ & $\begin{array}{l}6.991^{* *} \\
(2.19)\end{array}$ & $\begin{array}{l}.348^{*} \\
(1.72)\end{array}$ & $\begin{array}{l}6.297^{\star *} \\
(2.21)\end{array}$ & $\begin{array}{l}.629^{*} \\
(1.75)\end{array}$ & $\begin{array}{l}6.014^{\star *} \\
(2.19)\end{array}$ & $\begin{array}{l}.315 \\
(1.19)\end{array}$ & $\begin{array}{l}5.467^{\star \star} \\
(2.16)\end{array}$ & $\begin{array}{l}-.011 \\
(-.41)\end{array}$ \\
\hline
\end{tabular}

B: Regressions

\begin{tabular}{|c|c|c|c|c|c|c|c|c|c|c|}
\hline \multirow{2}{*}{$\begin{array}{l}\text { Generalist } \\
\text { Share Cutoff } \\
\text { Year }\end{array}$} & \multicolumn{2}{|c|}{$10 \%$} & \multicolumn{2}{|c|}{$12.5 \%$} & \multicolumn{2}{|c|}{$15 \%$} & \multicolumn{2}{|c|}{$17.5 \%$} & \multicolumn{2}{|c|}{$20 \%$} \\
\hline & 1997 & 2002 & 1997 & 2002 & 1997 & 2002 & 1997 & 2002 & 1997 & 2002 \\
\hline \multicolumn{11}{|l|}{ oROA (DV) } \\
\hline R3 & $\begin{array}{l}.13^{\star \star} \\
(2.03)\end{array}$ & $\begin{array}{l}.136^{\star \star \star} \\
(3.77)\end{array}$ & $\begin{array}{l}.141^{\star *} \\
(2.07)\end{array}$ & $\begin{array}{l}.145^{\star \star \star} \\
(3.81)\end{array}$ & $\begin{array}{l}.158^{\star \star \star} \\
(2.33)\end{array}$ & $\begin{array}{c}* 149^{\star \star} \\
(3.83)\end{array}$ & $\begin{array}{l}.137^{\star *} \\
(2.04)\end{array}$ & $\begin{array}{l}.132^{\star \star \star} \\
(2.94)\end{array}$ & ${ }^{*} \quad \begin{array}{c}.119^{*} \\
(1.95)\end{array}$ & $\begin{array}{l}.124^{\star \star} \\
(2.23)\end{array}$ \\
\hline $\mathrm{R} 3 \times$ market share & $\begin{array}{l}\text { e } .049^{* \star *} \\
(2.63)\end{array}$ & $\begin{array}{l}.066^{* *} \\
(2.01)\end{array}$ & $\begin{array}{l}.051^{\star * *} \\
(2.64)\end{array}$ & $\begin{array}{l}.069^{\star * *} \\
(2.04)\end{array}$ & $\begin{array}{l}.054^{* * *} \\
(2.70)\end{array}$ & $\begin{array}{l}.073^{* *} \\
(2.11)\end{array}$ & $\begin{array}{l}.043^{\star *} \\
(2.29)\end{array}$ & $\begin{array}{l}.061^{* *} \\
(2.00)\end{array}$ & $\begin{array}{l}.038^{\star \star} \\
(2.21)\end{array}$ & $\begin{array}{c}.048^{\star} \\
(1.87)\end{array}$ \\
\hline $\begin{array}{l}\mathrm{R} 3 \times \text { market } \\
\text { concentration }\end{array}$ & $\begin{array}{l}.081^{\star *} \\
(2.06) \\
.37\end{array}$ & $\begin{array}{l}.138^{\star \star \star} \\
(3.31) \\
.421\end{array}$ & $\begin{array}{c}.089^{\star \star} \\
(2.15) \\
.376\end{array}$ & $\begin{array}{l}.124^{\star \star \star} \\
(3.06) \\
.435\end{array}$ & $\begin{array}{c}.094^{\star * *} \\
(2.33) \\
.403\end{array}$ & $\begin{array}{c}.139^{* * *} \\
(3.34) \\
.448\end{array}$ & $\begin{array}{c}.079^{\star *} \\
(2.05) \\
.369\end{array}$ & $\begin{array}{l}.128^{\star \star \star} \\
(3.09) \\
.429\end{array}$ & $\begin{array}{c}.061^{*} \\
(1.94) \\
.312\end{array}$ & $\begin{array}{l}.108^{\star \star \star} \\
(2.54) \\
.391\end{array}$ \\
\hline Ditch & $\begin{array}{l}-.038^{\star * *} \\
(-2.73)\end{array}$ & $\begin{array}{l}-.054^{* \star \star} \\
(-2.56)\end{array}$ & $\begin{array}{l}-.032^{* * *} \\
(-2.67)\end{array}$ & $\begin{array}{l}-.048^{* \star *} \\
(-2.37)\end{array}$ & $\begin{array}{l}-.020^{* *} \\
(-2.23)\end{array}$ & $\begin{array}{l}-.034^{\star *} \\
(-2.20)\end{array}$ & $\begin{array}{c}-.018^{*} \\
(-1.94)\end{array}$ & $\begin{array}{l}-.027^{\star} \\
(-1.65)\end{array}$ & $\begin{array}{r}-.010 \\
(-1.53)\end{array}$ & $\begin{array}{r}-.020 \\
(-1.61)\end{array}$ \\
\hline Adjusted $\mathrm{R}^{2}$ & .317 & .316 & .298 & .271 & .281 & .234 & .240 & .021 & .211 & .198 \\
\hline
\end{tabular}

${ }^{*} p<.10$.

${ }^{* *} p<.05$.

${ }^{* * *} p<.01$.

Notes: G0, G1, G2, and G4 denote industries with $0,1,2$, and 4 generalists, respectively, and G5+ denotes industries with 5 or more generalists.

berg 1994). Nevertheless, our findings reaffirm that structural differences are too important to be overlooked by top management in strategic thinking and decision making. Perhaps the pendulum of practitioner (and academic) attention that used to be directed solely toward external/industry factors has now swung too far toward the internally focused resource-based perspective of strategic management (Boone, Carroll, and Van Witteloostuijn 2004). There is a need to advance and integrate both perspectives for gestalt.

\section{Implications for Marketing}

A primary responsibility of marketing is to drive sales. In this pursuit, marketing can create selective demand and significantly grow the market share of a firm organically. However, a superseding responsibility of marketing is to improve and maintain business profitability through brand, customer, and channel equity. When the costs and risks of market share growth (e.g., customer acquisition) threaten performance, marketing can also create primary demand and provide growth without necessarily changing market share. For the market leader approaching the upper limits of its economies of scale, it might make sense to use marketing to expand the pie and protect share rather than maximize share. Thus, large generalists have much to gain from comarketing with generalists in other industries or even with their direct competitors. The new focus would be on customer recruitment from nonusers instead of annexing customers from competitors. In some cases, this means a complete reconsideration and restructuring of how these firms deploy their big marketing budgets. Furthermore, not growing market share in the domestic market may also suggest an international growth strategy or even a globalization imperative.

Our finding that specialists generally perform better than ditch dwellers runs contrary to most industrial organization literature and challenges the mainstream PIMS-based literature, which traditionally views high-performing small firms merely as exceptions (Buzzell and Gale 1987). This 
traditional view is myopic in that niche players have a collectively substantial role within the confines of differentiated markets. In contrast, we find high-performing, smallmarket-share firms to be the rule rather than the exception. At first glance, the main implication for specialists appears to be to forsake share growth and stay small. Yet this may not necessarily be the case. We believe that the real message is to remain focused on core competencies (Hamel and Prahalad 1994) rather than to divert strategic attention toward firm size or market share. Because of their refined focus in their relevant markets, specialists can actually enjoy market leadership in their niches (Sheth and Sisodia 2002). They may even establish themselves as margin leaders. Thus, the financial performance of specialists may actually improve when they market to enhance their (target customer) share of heart and wallet within their niche but not necessarily when they grow their overall market share.

\section{Implications for the Investor Community}

Our findings also raise several substantial points that should be explored in further interdisciplinary collaboration between colleagues in marketing and finance. These include but are not limited to the following: First, there appears to be a prevalent R3 industry structure for which performance benefits are not accurately priced by capital markets. The disequilibrium in markets implied by our findings suggests that a portfolio of firms from R3 industries should outperform a portfolio of firms from other industry structures, all else being equal. Moreover, the conventional practice to invest in "the best of breed" of any industry to build a diversified portfolio appears sensible only when the number-one generalist is not overly dominant. Excessively dominant players get undue respect in financial markets even though their upside potential is limited.

Second, capital markets usually penalize the stock of the acquirer and boost that of the target when merger news are announced (Jensen and Ruback 1983). Our research implies that both stocks may be warranted a boost if a proposed M\&A decreases/increases the number of generalists to (or toward) three. Furthermore, because an R3 structure enhances overall industry performance, the financial markets' reaction to other stocks (in the same industry) should also be favorable when M\&A that converges industry structure to (or toward) an R3 structure is announced, and vice versa if M\&A diverts from R3. Similar reactions in financial markets have recently been shown to occur in response to phenomena that alter industry structure, such as privatization (e.g., Altintig et al. 2009) and divestitures (Lamont and Polk 2002).

Finally, ditch dwellers (i.e., those with intermediate market share) are not good long-term investments but may make excellent speculative investments in a portfolio, because their implied financial vulnerability makes them likely M\&A targets. Merger-and-acquisition activity can offer dramatic short-term boosts to stocks of target firms (Jensen and Ruback 1983).

\section{Further Research and Limitations}

The Rule of Three (Sheth and Sisodia 2002) contains unique perspectives and many important generalizations that demand further attention. Our examination focused entirely on the market structure-profitability relationships of firms in the United States. We did not examine the Rule of Three comprehensively, and several noteworthy propositions remain for further research. One such line of inquiry is the examination of R3 structures in other markets (e.g., European Union) and globally.

The Rule of Three also allows for predictions regarding industry evolution and dynamics. Although we used the most current data available, it would be worthwhile to use historical data and determine how successfully the Rule of Three could predict industry shakeouts and industry-specific and firm-specific profitability changes over time and in conjunction with other variables. In particular, the interplay among R3 industry structure, market share, and market concentration appears complex. A deeper examination of industry structure as a moderator is left for future work. Use of longitudinal data would also enhance the understanding of industry dynamics and may potentially reveal a feedback loop effect from profitability to market share/concentration.

The current research represents the first attempt to test the lawlike generalizations represented by the Rule of Three. As a result, it focused on the consistent effects rather than the differences (in direction and magnitude) among industries. In other words, although our study attempted to extract the overall generalizations outlined in the Rule of Three, there remain conditional or situational factors that might influence its relevance and, thus, its applicability. It would be worthwhile to ascertain the extent to which the Rule of Three is applicable to special cases (e.g., pure network industries), to top performers (using data envelopment analysis), or to specific industry and firm groups. For example, Schwalbach (1991) finds stronger profitability effects for market share within service industries.

The research to date involving specialists/generalists has predominantly been conducted in single-industry studies and case settings in which some researchers were able to distinguish between specialists and generalists according to niche width. In contrast, our study involved more than 1300 firms from more than 160 industries. Therefore, we did not categorize specialists, generalists, or the ditch dwellers on the basis of actual strategic focus. As a result, a small proportion of firms may have been misclassified (e.g., a specialist with more than $10 \%$ market share would be categorized as a generalist, or a generalist with less than 5\% market share would be categorized as a specialist). We have done our best to address this issue by using a variety of threshold values to demonstrate the robustness of the findings.

The private sector (firm and investor) benefits of the R3 structure appear to be clear and robust. However, to thoroughly assess the claimed absolute optimality of the structure, its impact (beyond economic efficiency) on a wide array of consumer welfare factors (i.e., consumer surplus, innovation, variety, customer satisfaction, convenience, affordability, price stability, and perceived value) could be examined in further research. Nevertheless, the Rule of 
Three has vast potential for straightforward public policy recommendations, especially with regard to M\&A activity and antitrust.

Furthermore, the Rule of Three may be inherently linked back to basic consumer behavior through the notion of the "evoked set" because most consumers and industrial buyers consider approximately three alternatives during the purchasing process (Howard and Sheth 1969; Sheth and Sisodia 2002). If so, the transformation and impact of the evoked set of consumer brands on corporate performance represent a worthwhile line of research for consumer behaviorists, marketing strategists, and marketing modelers alike.

Note that we do not argue that market share is the only, or even the main, determinant of performance. When considering a relationship between industry structure and profitability, it is challenging (if not impossible) to move beyond mere correlation to a determination of causality (Demsetz 1986; Slade 2004; Wensley 1997). Nonetheless, our analyses of market share as a leading indicator of performance indicates that it might indeed be related to subsequent firm earnings. As Boulding and Staelin (1993, p. 164) note, market share "has strategic value, under certain conditions, in that it generates lower costs and thus excess profits." We readily acknowledge that the basic relationship between market share and performance is mediated/moderated by additional factors and that these indirect effects could surpass and suppress the direct effect (Prescott, Kohli, and Venkatraman 1986). Although we attempted to control for the effects of such unobserved variables by including firmspecific dummy variables in our regression models, other systemic macroeffects may have affected our cross-sectional estimates. Finally, our data suffer from some of the same weaknesses as PIMS. ${ }^{3}$

In conclusion, there appears to be a rich vein of both theoretical and practical implications that can be drawn from Sheth and Sisodia's (2002) Rule of Three. Furthermore, the financial markets do not seem to price these implications fully into firm valuations. We advocate for further exploration of the theory and integration of its insights into business school curricula. We hope that this pioneering empirical examination will stimulate further research and advance the conceptualization of these fundamental relationships.

\section{Appendix Robustness Checks}

Because of the controversial nature of some of our hypotheses, we undertook extensive efforts to conduct additional robustness checks of our findings. We summarize these here.

\footnotetext{
${ }^{3}$ As with most PIMS-based studies on the market shareprofitability relationship, our approach relies on cross-sectional analysis of pooled data. Nonetheless, our methodology offers two significant advantages over those using PIMS data. First, we used objective market share data and SEC-reported accounting measures instead of self-reported "served market" measures and disguised financial figures. Second, we captured the small-share firms that report to the SEC, which enabled us to compare the performance of small firms that are typically excluded from PIMSbased studies (Day 1986).
}

\section{Market Definition}

Market share measurement is highly sensitive to how markets are defined. Thus, we repeated our analyses using fourdigit and three-digit NAICS classifications and two measures of relative market share (benchmarking against the top competitor and the top three competitors) when applicable. All results were consistent with theory and qualitatively the same.

\section{Industry Maturity}

Although we used a more inclusive 15-year cutoff to define industry maturity, 20- and 30-year cutoffs yielded qualitatively equivalent results.

\section{Alternative Performance Measures}

We also used oROS (operating income of the firm or unit divided by the total sales of the firm or unit) and three-year oROS as performance measures for all tests and revealed results similar to those of oROA tests. These further bolstered the reliability of the findings because ROS provides significantly more conservative estimates of the market share-profitability relationship (Szymanski, Bharadwaj, and Varadarajan 1993).

\section{Methodological Considerations}

We repeated all univariate tests for the medians using Wilcoxon sign-rank tests, and the results were qualitatively unchanged. We used multiple approaches for the CAR calculations: We used geometric mean instead of arithmetic mean in calculating CAR to account for compound effects of growth. We also calculated arithmetic mean results for robustness, which yielded stronger results; however, the more conservative geometric results were reported.

\section{Financial Measures}

Another common method of calculating long-term stock market performance in finance literature is to take the difference between the aggregate return on the stock and the aggregate return on a market portfolio (e.g., Ritter 1991). We also used this methodology to check for robustness. The results were stronger and in the same direction. However, because this method does not adjust for risk, we report the more conservative risk-adjusted results. In addition to the CRSP value-weighted index, we used the CRSP equally weighted index as a proxy for the market portfolio. The results remained qualitatively unchanged. We also checked alternative estimation periods for the systematic risk factor $\beta$ for robustness. Most common periods used in the finance literature are three, five, or ten years before the abnormal return calculation date (Barber and Lyon 1997). The results using $[-60,-12]$ months and $[-36,-12]$ months around the abnormal return calculation were qualitatively the same. We conservatively report the results with the longest estimation period (i.e., ten years).

\section{The Ditch/Generalist Distinction}

Theoretically, generalists and specialists are best distinguished by strategic breadth versus focus, an approach well suited for single-industry studies (Peli and Nooteboom 
1999). However, in practice, generalists (specialists) in mature industries are consistently characterized and measured as relatively large (small) in size, market share, and industry influence (e.g., Sorenson et al. 2006). As we noted previously, several researchers also identify a range of intermediate market share in which firms tend to perform worse. In the operationalization of these distinctions, the issue emerges of how best to demarcate the boundaries between these market share regions. Sheth and Sisodia (2002) argue for a $10 \%$ threshold dividing generalists and ditch firms. Similarly, Buzzell, Gale, and Sultan (1975) suggest the existence of a minimum critical share level, observing that profitability typically decreases when firms have less than $10 \%$ market share. Various researchers in economics have empirically demonstrated that market power (manifested as a positive influence on profitability) consistently emerges when the largest firms control a combined minimum of 45\%-59\% market share (Parry and Bass 1990; Rhodes and Cleaver 1973; Scherer 1980). Under conservative reasoning, the largest minimum firm size necessary to exert this influence in an R3 industry would be one-third of this requisite combined share (i.e., 15\%-20\%). Buzzell and Wiersama (1981) observe that the ratio that best fits the actual distribution of market share is .63 of the next-largest firm (tending to range from .6 to .65). Conservatively, when we use the largest combined share identified as imparting market power (i.e., 59\%), this size distribution results in the third-largest firm possessing a market share of slightly above $10 \%$ (i.e., 10.28\%). Using similar logic, Henderson (see BCG 1976; Henderson 1979) claims that no firm can be viable if it has less than $25 \%$ of the largest competitor's market share. Given that the average market share of the top generalists is approximately $41 \%$ in our R3 industry sample and $39 \%$ in our overall sample, the third-largest firm would have approximately $10 \%$ market share using this .5 ratio (4:2:1 proportion). Thus, with our sample averages, $10 \%$ also emerges as a defensible minimum cutoff choice. However, Henderson (see BCG 1976; Henderson 1979) claims, and Kwoka (1979) finds, that an individual firm market share of at least $15 \%$ is required to have a positive influence over industry profit levels. ${ }^{4}$ As a result of these plural perspectives, and with the goal of maximizing the generalizability of our findings, we examined the issue of market power using a broad range of generalist/ditch thresholds (see Table 7).

We conducted additional sensitivity analyses to establish the boundary market share conditions for each category. For generalists, analyses repeated at every percentage point revealed that significance of the results disappeared outside the 9\%-21\% market share range. Similarly, for specialists, analyses were repeated at every .5 percentage point, and significance of the results disappeared outside the 3\%-7\% range. Therefore, we consider the findings robust for alternative specifications of market share.

4Henderson's (BCG 1976) article (which argues for a 4:2:1 ratio) would not accommodate a third competitor with $15 \%$ market share, because the combined market share of the top three would then become $15 \%+30 \%+60 \%=105 \%$, even without accounting for any specialists.

\section{REFERENCES}

Adrian, Tobias and Joshua Rosenberg (2008), "Stock Returns and Volatility: Pricing the Short-Run and Long-Run Components of Market Risk," Journal of Finance, 63 (December), 2997-3030.

Ailawadi, Kusum L., Paul W. Farris, and Mark E. Parry (1999), "Market Share and ROI: Observing the Effect of Unobserved Variables," International Journal of Research in Marketing, 16 (1), 17-33.

Aldrich, Howard E. (1999), Organizations Evolving. Thousand Oaks, CA: Sage Publications.

Altintig, Z. Ayca, K. Peren Arin, Eberhard Feess, and Christoph Schumacher (2009), "You Are One of Us Now! How Do Share Prices of Rivals React to Privatization?" Journal of Industrial Economics, 57 (2), 265-93.

Amburgey, Terry L., Tina Dacin, and Dawn Kelly (1994), “Disruptive Selection and Population Segmentation: Interpopulation Competition as a Segregation Process," in Evolutionary Dynamics of Organizations, Joel A.C. Baum and Jitendra V. Singh, eds. New York: Oxford University Press, 240-54.

Anderson, Carl R. and Frank T. Paine (1978), "PIMS: A Reexamination," Academy of Management Review, 4 (July), 602-612.

Anderson, Eugene W., Claes Fornell, and Donald R. Lehmann (1994), "Customer Satisfaction, Market Share, and Profitability: Findings from Sweden," Journal of Marketing, 58 (July), 53-66.

Armstrong, J. Scott and Fred Collopy (1996), "Competitor Orientation: Effects of Objectives and Information on Managerial Decisions and Profitability," Journal of Marketing Research, 33 (May), 188-99.

Audretsch, David B. (1995), Innovation and Industry Evolution. Cambridge, MA: MIT Press.
, Yvonne M. Prince, and A. Roy Thurik (1999), "Do Small Firms Compete with Large Firms?" Atlantic Economic Journal, 27 (June), 201-209.

Axtell, Robert L. (2001), "Zipf Distributions of U.S. Firm Sizes," Science, (September 7), 1818-20.

- (2006), "Firm Sizes: Facts, Formulae, Fables and Fantasies," CSED Working Paper No. 44, The Brookings Institution, Washington, DC.

Bain, Joe S. (1956), Barriers to New Competition. Cambridge, MA: Harvard University Press.

Barber, Brad M. and John D. Lyon (1997), "Detecting Long-Run Abnormal Stock Returns: The Empirical Power and Specification of Test Statistics," Journal of Financial Economics, 43 (3), 341-72.

BCG (1976), "The Rule of Three and Four," Perspectives, No. 187. Boston: Boston Consulting Group.

Berger, Alan N., Rebecca S. Demsetz, and Philip E. Strahan (1999), "The Consolidation of the Financial Services Industry: Causes, Consequences, and Implications for the Future," Journal of Banking and Finance, 23 (2-4), 135-94.

Bharadwaj, Sundar G. and P. Rajan Varadarajan (2005), "Toward an Integrated Model of Business Performance," Review of Marketing Research, 1 (1), 207-243.

Bloom, Paul N. and Philip Kotler (1975), "Strategies for High Market Share Companies," Harvard Business Review, 53 (November-December), 63-72.

Boone, Christophe, Glenn R. Carroll, and Arjen van Witteloostuijn (2004), "Size, Differentiation and the Performance of Dutch Daily Newspapers," Industrial and Corporate Change, 13 (1), 117-48. 
Boulding, William and Richard Staelin (1990), "Environment, Market Share, and Market Power," Management Science, 36 (October), 1160-77.

- and (1993), "A Look on the Cost Side: Market Share and the Competitive Environment," Marketing Science, 12 (Spring), 144-66.

Branch, Ben S. (1980), "The Laws of the Marketplace and ROI Dynamics," Financial Management, 9 (Summer), 58-65.

Buzzell, Robert D. (1981), "Are There 'Natural' Market Structures?” Journal of Marketing, 45 (Winter), 42-51.

_ (2004), "The PIMS Program of Strategy Research: A Retrospective Appraisal," Journal of Business Research, 57 (May), 478-83.

- and Bradley T. Gale (1987), The PIMS Principles: Linking Strategy to Performance. New York: The Free Press.

$\longrightarrow$, - Ralph G.M. Sultan (1975), "Market Share: A Key to Profitability," Harvard Business Review, 53 (1), 97-106.

— and Frederik D. Wiersama (1981), "Successful ShareBuilding Strategies," Harvard Business Review, 59 (1), 135-44.

Carroll, Glenn R. (1985), "Concentration and Specialization: Dynamics of Niche Width in Populations of Organizations," American Journal of Sociology, 90 (6), 1261-83.

- (1997), "Long-Term Evolutionary Change in Organizational Populations: Theory, Models and Empirical Findings in Industrial Demography," Industrial and Corporate Change, 6 (1), 119-43.

- S.D. Dobrev, and A. Swaminathan (2002), "Organizational Processes of Resource Partitioning," in Research in Organizational Behavior, Vol. 24, R.I. Sutton and B.M. Staw, eds. Greenwich, CT: JAI Press, 1-40.

_ and Michael T. Hannan (2000), The Demography of Corporations and Industries. Princeton, NJ: Princeton University Press.

Caves, Richard E., Michael Fortunato, and Pankaj Ghemawat (1984), "The Decline of Dominant Firms, 1905-1929," The Quarterly Journal of Economics, 99 (3), 523-46.

$\longrightarrow$ and Michael E. Porter (1977), "From Entry Barriers to Mobility Barriers: Conjectural Decisions and Contrived Deterrence to New Competition," Quarterly Journal of Economics, 91 (2), 241-62.

Cialdini, Robert B. (1993), Influence: The Psychology of Persuasion. New York: Morrow.

Day, George S. (1986), Analysis for Strategic Market Decisions. St. Paul, MN: West Publishing.

Demsetz, Harold (1973), "Industry Structure, Market Rivalry, and Public Policy," Journal of Law and Economics, 16 (1), 1-9.

_ (1986), "Industry Structure, Market Rivalry, and Public Policy," in Organizational Economics: Toward a New Paradigm for Understanding and Studying Organizations, Jay B. Barney and William G. Ouchi, eds. San Francisco: JosseyBass, 414-22.

Dobrev, Stanislav D. and Glenn R. Carroll (2003), "Size (and Competition) Among Organizations: Modeling Scale-Based Selection Among Automobile Producers in Four Major Countries, 1885-1981," Strategic Management Journal, 24 (6), 541-58.

Douglas, Susan P. and Samuel C. Craig (1983), "Examining Performance of U.S. Multinationals in Foreign Markets," Journal of International Business Studies, 14 (Winter), 51-62.

Drucker, Peter F. (1982), The Changing World of the Executive. New York: Times Books.

Ehrenberg, Andrew, Gerald Goodhardt, and T. Patrick Barwise (1990), "Double Jeopardy Revisited," Journal of Marketing, 54 (July), 82-91.
Farris, Paul and Michael J. Moore (2004), The Profit Impact of Marketing Strategy Project: Retrospect and Prospects. Cambridge, UK: Cambridge University Press.

_ tural Analysis of Models with Composite Dependent Variables," Marketing Science, 11 (1), 76-94.

Fornell, Claes (1995), “The Quality of Economic Output: Empirical Generalizations About Its Distribution and Relationship to Market Share," Marketing Science, 14 (3) (Part 2 of 2), G203-G211.

Gale, Bradley T. and Ben S. Branch (1982), "Concentration Versus Market Share: Which Determines Performance and Why Does It Matter?” The Antitrust Bulletin, 27 (Spring), 83-103.

Gans, Joshua S. and John Quiggin (2003), "A Technological and Organisational Explanation for the Size Distribution of Firms," Small Business Economics, 21 (3), 243-56.

Geroski, P.A. (1987), "Do Dominant Firms Decline?" in The Economics of Market Dominance, D. Hay and J. Vickers, eds. New York: Basil Blackwell, 143-67.

Gordon, R.M. (2001), "The Rule of Three: Surviving and Thriving in Competitive Markets," Marketing Management, 10 (NovemberDecember), 53-54.

Hamel, Gary and C.K. Prahalad (1994), Competing for the Future. Boston: Harvard Business School Publishing.

Hamermesh, Richard G., M.J. Anderson Jr., and J.E. Harris (1978), "Strategies for Low Market Share Businesses," Harvard Business Review, 56 (May-June), 95-102.

Hannan, Michael T. and John Freeman (1977), "The Population Ecology of Organizations," American Journal of Sociology, 82 (5), 929-64.

Hellofs, Linda L. and Robert Jacobson (1999), "Market Share and Customers' Perceptions of Quality: When Can Firms Grow Their Way to Higher Versus Lower Quality?" Journal of Marketing, 63 (January), 16-25.

Henderson, Bruce D. (1979), Henderson on Corporate Strategy. Cambridge, MA: Abt Books.

Henricks, Mark (2002), "Also-Rans," Entrepreneur, 30 (4), 25.

Howard, John and Jagdish N. Sheth (1969), The Theory of Buyer Behavior. New York: John Wiley \& Sons.

Huck, Steffen, Hans-Theo Normann, and Jorg Oechssler (2004), "Two Are Few and Four Are Many: Number Effects in Experimental Oligopolies," Journal of Economic Behavior \& Organization, 53 (4), 435-46.

Hunt, Shelby D. (2002), Foundations of Marketing Theory. Armonk, NY: M.E. Sharpe.

Ijiri, Yuji and Herbert A. Simon (1977), Skew Distributions and the Sizes of Business Firms. New York: Elsevier/North-Holland.

Jacobson, Robert (1988), "Distinguishing Among Competing Theories of the Market Share Effect," Journal of Marketing, 52 (October), 68-80.

(1990), "Unobservable Effects and Business Performance," Marketing Science, 9 (1), 74-85.

Jayachandran, Satish, Javier Gimeno, and P. Rajan Varadarajan (1999), "The Theory of Multimarket Competition: A Synthesis and Implications for Marketing Strategy," Journal of Marketing, 63 (July), 49-66.

Jensen, Michael C. and Richard Ruback (1983), "The Market for Corporate Control: The Scientific Evidence," Journal of Financial Economics, 11 (1-4), 5-50.

Karakaya, Fahri and Michael J. Stahl (1989), "Barriers to Entry and Market Entry Decisions in Consumer and Industrial Goods Markets," Journal of Marketing, 53 (April), 80-91.

Klepper, Steven and Kenneth L. Simons (1997), “Technological Extinctions of Industrial Firms: An Inquiry into Their Nature and Causes," Industrial and Corporate Change, 6 (2), 379-460.

Kohli, Ajay K., N. Venkatraman, and John H. Grant (1990), "Exploring the Relationship Between Market Share and Busi- 
ness Profitability," in Research in Marketing, Vol. 10, Jagdish Sheth, ed. Greenwich, CT: JAI Press, 113-33.

Kotabe, Masaaki, Dale F. Duhan, David K. Smith Jr., and R. Dale Wilson (1991), "The Perceived Veracity of PIMS Strategy Principles in Japan: An Empirical Inquiry," Journal of Marketing, 55 (January), 26-41.

Kuester, Sabine, Christian Homburg, and Thomas S. Robertson (1999), "Retaliatory Behavior to New Product Entry," Journal of Marketing, 63 (October), 90-106.

Kwoka, John E., Jr. (1979), "The Effect of Market Share Distribution on Industry Performance," The Review of Economics and Statistics, 61 (1), 101-109.

Lamont, Owen A. and Christopher Polk (2002), "Does Diversification Destroy Value? Evidence from the Industry Shocks," Journal of Financial Economics, 63 (January), 51-77.

Landry, John T. (2002), "The Rule of Three: Surviving and Thriving in Competitive Markets," Harvard Business Review, 80 (1), 23.

Lodish, Leonard M. and Carl F. Mela (2007), "If Brands Are Built over Years, Why Are They Managed over Quarters?" Harvard Business Review, 85 (July-August), 104-112.

Luo, Xueming and Christian Homburg (2008), "Satisfaction, Complaint, and the Stock Value Gap," Journal of Marketing, 72 (July), 29-43.

Mainkar, Avinash V., Michael Lubatkin, and William S. Schulze (2006), "Towards a Product-Proliferation Theory of Entry Barriers," Academy of Management Review, 31 (4), 1062-1075.

Mascarenhas, Briance (1995), "International Industry Evolution Patterns," International Business Review, 4 (2), 233-46.

Mezias, John M. and Stephen J. Mezias (2000), "Resource Partitioning, the Founding of Specialist Firms, and Innovation: The American Feature Film Industry, 1912-1929," Organization Science, 11 (3), 306-322.

Miller, Richard A. (1967), "Marginal Concentration Ratios and Industrial Profit Rates: Some Empirical Results of Oligopoly Behavior," Southern Economic Journal, 34 (2), 259-67.

Mintzberg, Henry (1994), "The Fall and Rise of Strategic Planning," Harvard Business Review, 72 (1), 107-114.

Nelson, Richard R. and Sidney Winter (1982), An Evolutionary Theory of Economic Change. Cambridge, MA: The Belknap Press/Harvard University Press.

Neter, John, Michael H. Kutner, Christopher J. Nachtsheim, and William Wasserman (1996), Applied Linear Statistical Models, 4th ed. Boston: McGraw-Hill.

Nooteboom, Bart (1994), "Innovation and Diffusion in Small Firms: Theory and Evidence," Small Business Economics, 6 (5), 327-47.

Parry, Mark and Frank M. Bass (1990), "When to Lead or Follow? It Depends," Marketing Letters, 1 (3), 187-98.

Peli, Gabor and Bart Nooteboom (1999), "Marketing Partitioning and the Geometry of Resource Space," American Journal of Sociology, 104 (4), 1132-53.

Porter, Michael E. (1979), "The Structure Within Industries and Companies' Performance," Review of Economics and Statistics, 61 (2), 214-27.

- (1980), Competitive Strategy. New York: The Free Press.

Prescott, John E., Ajay Kohli, and N. Venkatraman (1986), "The Market Share-Profitability Relationship: An Empirical Assessment of Major Assertions and Contradictions," Strategic Management Journal, 7 (4), 377-94.

Quandt, Richard E. (1966), "On the Size Distribution of Firms," American Economic Review, 56 (3), 416-32.

Ramanujam, Vasudevan and N. Venkatraman (1984), "An Inventory and Critique of Strategy Research Using the PIMS Database," Academy of Management Review, 9 (1), 138-51.

Rhodes, Steven A. and Joe M. Cleaver (1973), "The Nature of the Concentration-Price/Cost Margin Relationship for 352 Manufacturing Industries: 1967," Southern Economic Journal, 39 (April), 90-102.
Ritter, Jay R. (1991), "The Long-Run Performance of Initial Public Offerings," Journal of Finance, 46 (1), 3-27.

Ritz, Robert A. (2008), "Strategic Incentives for Market Share," International Journal of Industrial Organization, 26 (March), 586-97.

Rumelt, Richard P. and Robin Wensley (1981), "In Search of the Market Share Effect," in Proceedings of the Annual Meeting of the Academy of Management Conference. Detroit: Academy of Management, 1-6.

Saffersfone, Mark J. (2002), "The Rule of Three: Surviving and Thriving in Competitive Markets," Academy of Management Executive, 16 (3), 161-62.

Scherer, Frederic M. (1980), Industrial Market Structure and Economic Performance, 2d ed. Boston: Houghton Mifflin.

and David Ross (1990), Industrial Market Structure and Economic Performance, 3d ed. Boston: Houghton Mifflin.

Schmalensee, Richard (1989), "Inter-Industry Studies of Structure and Performance," in Handbook of Industrial Organization, R. Schmalensee and R.D. Willig, eds. Oxford: Elsevier, 951-1009.

Schwalbach, Joachim (1991), "Profitability and Market Share: A Reflection on the Functional Relationship," Strategic Management Journal, 12 (May), 299-307.

Sharp, Byron, Erica Riebe, John Dawes, and Nick Danenberg (2002), "A Marketing Economy of Scale: Big Brands Lose Less of Their Customer Base than Small Brands," Marketing Bulletin, 13, Research Note 1.

Shepherd, William. G. (1972), "The Elements of Market Structure," Review of Economics and Statistics, 54 (1), 25-37. (1990), "The Treatment of Market Dominance," Review of Industrial Organization, 5 (2), 127-54.

Sheth, Jagdish N. and Rajendra S. Sisodia (1998), "Only the Big Three Will Survive," The Wall Street Journal, Eastern ed., (November 5), A22.

and (2002), The Rule of Three: Surviving and Thriving in Competitive Markets. New York: The Free Press.

Simon, Herbert A. and C.P. Bonini (1958), "The Size Distributions of Business Firms," American Economic Review, 48 (September), 607-617.

Slade, Margaret E. (2004), "Competing Models of Firm Profitability," International Journal of Industrial Organization, 22 (March), 289-308.

Smallwood, Dennis and John Conlisk (1979), "Product Quality in Markets Where Consumers Are Imperfectly Informed," Quarterly Journal of Economics, 93 (February), 1-23.

Sorenson, Olav, Susan McEvily, Charlotte Rongrong Ren, and Raja Roy (2006), "Niche Width Revisited: Organizational Scope, Behavior, and Performance," Strategic Management Journal, 27 (10), 915-936.

Stigler, George J. (1964), “A Theory of Oligopoly,” The Journal of Political Economy, 72 (February), 44-61.

Swaminathan, Anand (2001), "Partitioning and the Evolution of Specialist Organizations: The Role of Location and Identity in the U.S. Wine Industry," Academy of Management Journal, 44 (6), 1169-85.

Szymanski, David M., Sundar G. Bharadwaj, and P. Rajan Varadarajan (1993), "An Analysis of the Market ShareProfitability Relationship," Journal of Marketing, 57 (July), $1-18$.

Wensley, Robin (1997), "Explaining Success: The Rule of Ten Percent and the Example of Market Share," Business Strategy Review, 8 (1), 63-70.

Woo, Carolyn Y. and Arnold C. Cooper (1981), "Strategies of Effective Low Share Businesses," Strategic Management Journal, 2 (3), 301-318.

and (1982), "The Surprising Case for Low Market Share," Harvard Business Review, 60 (November-December), 106-113. 
Copyright of Journal of Marketing is the property of American Marketing Association and its content may not be copied or emailed to multiple sites or posted to a listserv without the copyright holder's express written permission. However, users may print, download, or email articles for individual use. 